\title{
Experimental and theoretical studies on the effect of the oxo group in 1,4-benzodiazepines $\uparrow$
}

\author{
Pablo Pertejo, ${ }^{a}$ María García-Valverde, ${ }^{\text {a }}$ Pablo Peña, ${ }^{a}$ Nicolás A. Cordero, ${ }^{b}$ \\ Tomás Torroba ${ }^{a}$ and Alfonso González-Ortega ${ }^{c}$
}

Two families of regioisomeric 1,4-benzodiazepines, 4-benzyl-3H-benzo[e][1,4]diazepin-5-ones and 4-benzoyl-4,5-dihydro-3H-benzo[e][1,4]diazepines, have been synthesized through a similar Ugi/ reduction cyclization sequence. Their conformation and stability depend on the position of the tautomeric imine/enamine equilibrium present in the diazepine nucleus, which in turn depends on the relative position of the carbonyl group adjacent to the nitrogen at the 4-position in the benzodiazepine system. Moreover, the electrophilic center on the imine tautomer is essential for the antitumor activity of some benzodiazepines as a DNA binding position. The mechanism of tautomerization in the presence or absence of the oxo group has been studied computationally using DFT methods (B3LYP/6-31G** level).

Received 26th February 2014,

Accepted 9th May 2014

DOI: 10.1039/c4ob00444b

www.rsc.org/obc

\section{Introduction}

The Ugi reaction followed by post-condensation transformations constitutes a powerful synthetic tool for the preparation of pseudopeptidic structures. ${ }^{1}$ The synthesis of peptidomimetics capable of mimicking $\beta$-turn structures has gained interest for the discovery of new therapeutic agents, since the interaction between the peptide ligands and their receptor targets usually implies these structures. ${ }^{2}$ An approach to construct peptidomimetics involves the design of conformationally restricted analogs by incorporation of heterocycles to improve the characteristics of the receptor-bound conformation of the endogenous peptide. ${ }^{3}$

Following this strategy, we recently described the synthesis of a new group of pseudopeptidic $3 H$-benzo[e][1,4]diazepin$5(4 H)$-ones A (Fig. 1) by a sequential Ugi reaction-Staudinger/ aza-Wittig cyclization. ${ }^{4}$ Interestingly, the backbone of these heterocycles superimposes well with $\beta$-turn motifs, such as those in the $\delta$ antigen, LDL receptor module, acetyl-CoA carboxylase and erabutoxin $\mathrm{B},{ }^{5}$ which makes them useful candidates for designing new drugs.

Additionally a new series of 4-methoxycarbonyl-4,5-dihydro$3 H$-benzo[e][1,4]diazepines B (Fig. 1) has been described as

${ }^{a}$ Chemistry Department, Faculty of Science, University of Burgos, 09001-Burgos,

Spain

${ }^{b}$ Physics Department, Higher Polytechnic School, University of Burgos, 09001-Burgos, Spain

'Organic Chemistry Department, Faculty of Science, University of Valladolid, 47011-Valladolid, Spain

$\dagger$ Electronic supplementary information (ESI) available: Spectra of all new compounds and computational data. See DOI: 10.1039/c4ob00444b intermediates in the synthesis of fused hydantoin-benzodiazepines. ${ }^{6}$ The synthesis of these intermediates was carried out by a sequential Ugi reaction-deprotection cyclization employing an Ugi-5-component $\mathrm{CO}_{2}$ mediated condensation. We thought that the similitude of intermediates $\mathbf{B}$ with benzodiazepines $\mathbf{A}$ would be a good starting point in the design of new pseudopeptidic structures.

Following this idea, we planned the synthesis of two different families of regioisomeric benzodiazepines, 4-benzyl$3 H$-benzo[e][1,4]diazepin-5(4H)-ones type A and 4-benzoyl-4,5dihydro- $3 H$-benzo $[e][1,4]$ diazepines analogous to intermediate B, following a similar strategy. In the course of this work, we have observed that the position of the carbonyl group is crucial in the evolution of the imine-enamine tautomeric equilibrium present in the diazepine nucleus, which in turn is crucial for the conformation and stability of these systems and therefore for the development of new drugs. On the basis of the experimental results, we have carried out computational
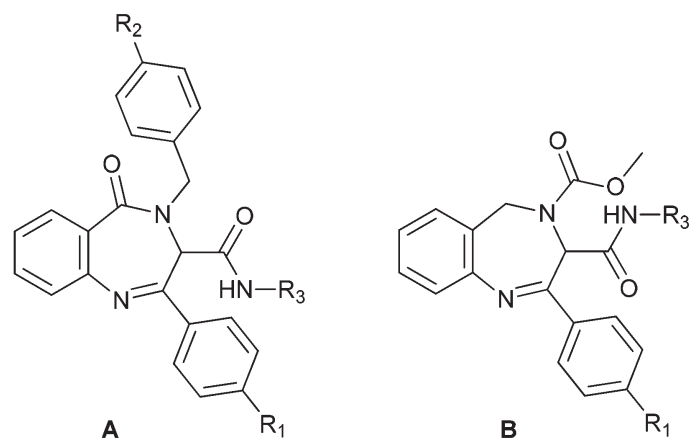

Fig. 1 1,4-Benzodiazepines synthesized using the Ugi reaction. 
studies to explain the different behaviors of these regioisomers.

$5 \quad$ Results and discussion

Looking for a general method for the synthesis of both families of benzodiazepines we thought that the methodologies previously developed for the synthesis of benzo[ $[e][1,4]$ diazepine-5-ones $\mathbf{A}^{4}$ or 4,5-dihydro-3H-benzo[e][1,4]diazepines B had several drawbacks. On the one hand, the Ugi-Staudinger/aza-Wittig methodology described in the synthesis of $\mathbf{A}$ used 2-azidobenzoic acid as the starting material for the Ugi reaction. This reagent had to be synthesized from anthranilic acid and sodium azide ${ }^{7}$ and the potential explosion hazard of azides discourages the use of this process. ${ }^{8}$ Moreover the Staudinger/aza-Wittig sequence requires anhydrous conditions, an inert atmosphere and generates large quantities of triphenylphosphine oxide which had to be eliminated by chromatography. ${ }^{9}$ On the other hand, the sequence Ugi/deprotection cyclization described in the synthesis of 4,5-dihydro- $3 H$-benzo$[e][1,4]$ diazepines $\mathbf{B}^{6}$ used ortho- $N$-Boc-benzylamine as the starting amine in the Ugi reaction, an amine that had to be synthesized from 2-aminobenzylamine in a three-step sequence resulting in a global process with a poor atom economy. ${ }^{10}$
These drawbacks prompted us to attempt a new sequence to overcome them, looking for a more ecofriendly, simple and scalable methodology, and basically a methodology easily applicable to the synthesis of both families of benzodiazepines under study in order to be able to compare the results obtained from their syntheses.

In this way we decided to use the Ugi reaction followed by a reduction cyclization sequence, choosing the nitro group as a masked amino group for subsequent cyclizations. Therefore, in the synthesis of benzo[e][1,4]diazepine-5-ones $\mathbf{A}$, we selected the commercially available 2-nitrobenzoic acid in place of 2-azidobenzoic acid as the carboxylic acid component in the Ugi reaction. Following the most common procedure, ${ }^{11}$ the corresponding imine was pre-formed by mixing substituted benzylamine $2 \mathbf{a}-\mathbf{e}$ ( 1 equiv.) with a solution of arylglyoxal $\mathbf{1 a - b}$ (1 equiv.) in methanol. Alkyl isocyanide $\mathbf{4 a - b}$ (1 equiv.) and 2-nitrobenzoic acid 3 ( 1 equiv.) were then added to the imine solution and the mixture was stirred at room temperature for one day until precipitation of Ugi products 5. Filtration and recrystallization of the solid afforded the Ugi adduct exclusively as an enol tautomer on the basis of NMR spectra (Table 1). ${ }^{4}$

The conversion of Ugi adducts 5 to 5 -oxobenzo[e][1,4]diazepin-3-carboxamides 6 was accomplished by reduction of the nitro group with subsequent cyclization. The key factor in the choice of the reduction methodology was the tolerance toward
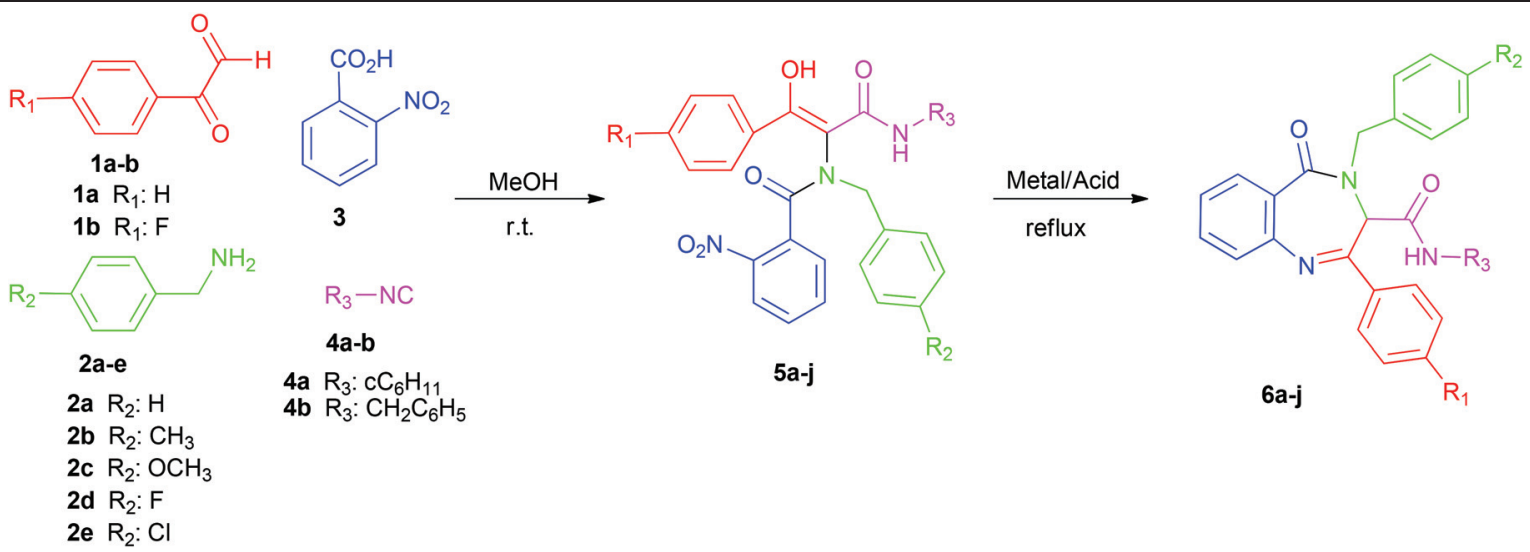

\begin{tabular}{|c|c|c|c|c|c|c|}
\hline Entry & $\mathbf{1}\left(\mathrm{R}^{1}\right)$ & $2\left(\mathrm{R}^{2}\right)$ & $4\left(\mathrm{R}^{3}\right)$ & $5^{a}(\%)$ & Metal/acid & $6^{a}(\%)$ \\
\hline 1 & $1 \mathrm{a}(\mathrm{H})$ & $2 \mathbf{a}(\mathrm{H})$ & $4 \mathbf{a}\left(c \mathrm{C}_{6} \mathrm{H}_{11}\right)$ & $5 \mathbf{a}(65)$ & $\mathrm{Fe} / \mathrm{AcOHb}$ & $6 \mathbf{a}(41)$ \\
\hline 2 & & & & & $\mathrm{Fe} / \mathrm{HCl}^{c}$ & 6a $(89)^{e}$ \\
\hline 3 & & & & & $\mathrm{SnCl}_{2} / \mathrm{HCl}^{d}$ & $6 a(85)$ \\
\hline 4 & $1 \mathrm{a}(\mathrm{H})$ & $2 \mathbf{b}\left(\mathrm{CH}_{3}\right)$ & $4 \mathbf{a}\left(c \mathrm{C}_{6} \mathrm{H}_{11}\right)$ & $5 \mathbf{b}(64)$ & $\mathrm{SnCl}_{2} / \mathrm{HCl}^{d}$ & $6 \mathbf{b}(84)$ \\
\hline 5 & $1 \mathrm{a}(\mathrm{H})$ & $2 \mathrm{c}\left(\mathrm{OCH}_{3}\right)$ & $4 \mathbf{a}\left(c \mathrm{C}_{6} \mathrm{H}_{11}\right)$ & $5 c(66)$ & $\mathrm{SnCl}_{2} / \mathrm{HCl}^{d}$ & 6c (91) \\
\hline 6 & $1 \mathrm{a}(\mathrm{H})$ & $2 d(F)$ & $4 \mathbf{a}\left(c \mathrm{C}_{6} \mathrm{H}_{11}\right)$ & 5d (65) & $\mathrm{SnCl}_{2} / \mathrm{HCl}^{d}$ & 6d (84) \\
\hline 7 & $1 \mathrm{a}(\mathrm{H})$ & $2 \mathrm{e}(\mathrm{Cl})$ & $4 \mathbf{a}\left(c \mathrm{C}_{6} \mathrm{H}_{11}\right)$ & $5 e(65)$ & $\mathrm{SnCl}_{2} / \mathrm{HCl}^{d}$ & $6 e(87)$ \\
\hline 8 & $1 \mathrm{~b}(\mathrm{~F})$ & $2 \mathrm{a}(\mathrm{H})$ & $4 \mathbf{a}\left(c \mathrm{C}_{6} \mathrm{H}_{11}\right)$ & $5 \mathbf{f}(57)$ & $\mathrm{SnCl}_{2} / \mathrm{HCl}^{d}$ & $6 f(82)$ \\
\hline 9 & $1 \mathrm{a}(\mathrm{H})$ & $2 \mathrm{a}(\mathrm{H})$ & $\mathbf{4 b}\left(\mathrm{CH}_{2} \mathrm{C}_{6} \mathrm{H}_{5}\right)$ & $5 g(66)$ & $\mathrm{SnCl}_{2} / \mathrm{HCl}^{d}$ & $6 \mathrm{~g}(83)$ \\
\hline 10 & $1 \mathrm{a}(\mathrm{H})$ & $2 \mathbf{b}\left(\mathrm{CH}_{3}\right)$ & $\mathbf{4 b}\left(\mathrm{CH}_{2} \mathrm{C}_{6} \mathrm{H}_{5}\right)$ & $5 \mathbf{h}(63)$ & $\mathrm{SnCl}_{2} / \mathrm{HCl}^{d}$ & $\mathbf{6 h}(81)$ \\
\hline 11 & $1 \mathrm{a}(\mathrm{H})$ & $2 \mathrm{c}\left(\mathrm{OCH}_{3}\right)$ & $4 \mathbf{b}\left(\mathrm{CH}_{2} \mathrm{C}_{6} \mathrm{H}_{5}\right)$ & $5 \mathbf{i}(69)$ & $\mathrm{SnCl}_{2} / \mathrm{HCl}^{d}$ & $6 \mathbf{i}(83)$ \\
\hline 12 & 1a $(\mathrm{H})$ & $2 \mathrm{e}(\mathrm{Cl})$ & $\mathbf{4 b}\left(\mathrm{CH}_{2} \mathrm{C}_{6} \mathrm{H}_{5}\right)$ & $5 \mathbf{j}(61)$ & $\mathrm{SnCl}_{2} / \mathrm{HCl}^{d}$ & $\mathbf{6 j}(87)$ \\
\hline
\end{tabular}

${ }^{a}$ Isolated yields. ${ }^{b} \mathrm{Fe}$ (10 equiv.), acetic acid, $70{ }^{\circ} \mathrm{C}, 3$ h. ${ }^{c} \mathrm{Fe}$ (10 equiv.), $\mathrm{HCl}$ (3 equiv.), ethanol, reflux, 45 min. ${ }^{d} \mathrm{SnCl}_{2}$ (10 equiv.), $\mathrm{HCl}(3$ equiv.), ethanol, reflux, 45 min. ${ }^{e}$ Isolated yield of benzodiazepine 6 a when the reduction was quantitative. 

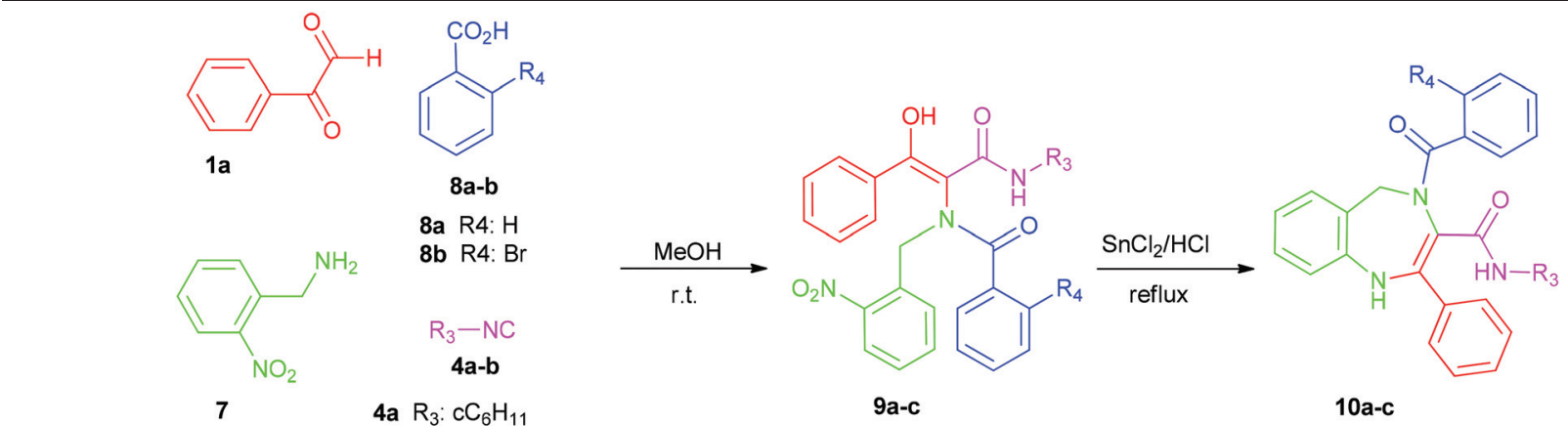

8b $\mathrm{R} 4: \mathrm{Br}$

$$
\begin{gathered}
\mathrm{R}_{3}-\mathrm{NC} \\
4 \mathbf{a}-\mathbf{b}
\end{gathered}
$$

9a-c

$10 \mathrm{a}-\mathrm{c}$

\begin{tabular}{llllr}
\hline Entry & $\mathbf{4}\left(\mathrm{R}^{3}\right)$ & $\mathbf{8}\left(\mathrm{R}^{4}\right)$ & $\mathbf{9}^{a}(\%)$ & $\mathbf{1 0}(\%)$ \\
\hline 1 & $\mathbf{4 b}\left(\mathrm{CH}_{2} \mathrm{C}_{6} \mathrm{H}_{5}\right)$ & $\mathbf{8 a}(\mathrm{H})$ & $\mathbf{9 a}(46)$ & $\mathbf{1 0 a}(59)$ \\
2 & $\mathbf{4 a}\left(\mathrm{CC}_{6} \mathrm{H}_{11}\right)$ & $\mathbf{8 b}(\mathrm{Br})$ & $\mathbf{9 b}(38)$ & $\mathbf{1 0 b}(61)$ \\
3 & $\mathbf{4 b}\left(\mathrm{CH}_{2} \mathrm{C}_{6} \mathrm{H}_{5}\right)$ & $\mathbf{8 b}(\mathrm{Br})$ & $\mathbf{9 d}(41)$ & $\mathbf{1 0 c}(62)$
\end{tabular}

${ }^{a}$ Isolated yields.

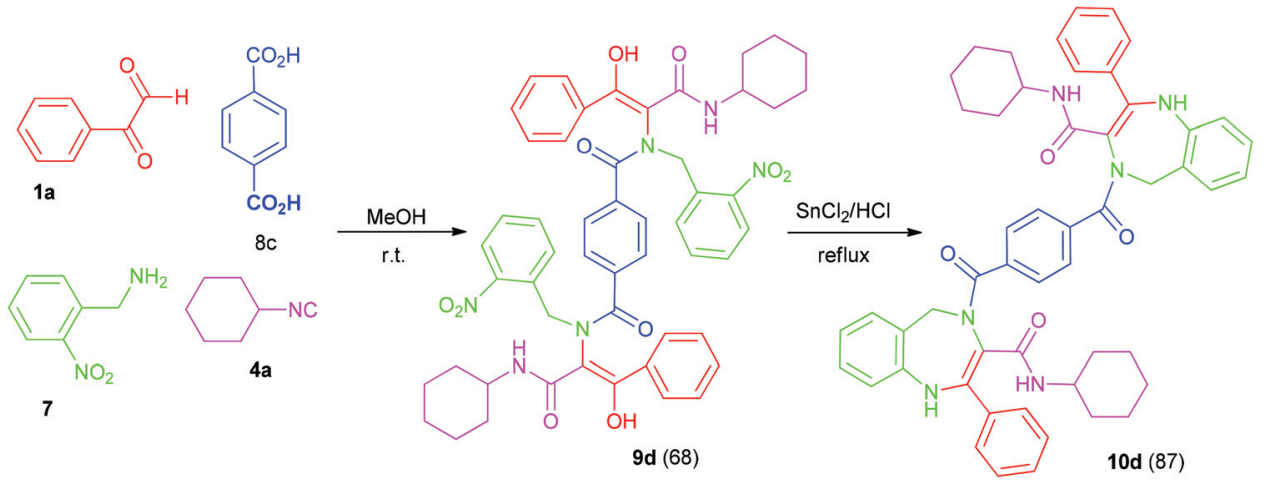

other functional groups present in reactants and/or products such as ketones, imines, benzyl amides or aryl halides.

Initially we investigated the use of iron in acetic acid, ${ }^{12}$ but the reduction took place with poor conversion (Table 1, entry 1). We then tried the reduction with iron and hydrochloric acid in hot ethanol, ${ }^{13}$ and although the initial results were promising (Table 1, entry 2), conversions were not consistent from run to run, depending on several factors such as temperature, concentration or stirring efficiency. ${ }^{14}$

Looking for a more robust method, we studied the reducing ability of stannous chloride in the presence of hydrochloric acid. ${ }^{15}$ Fortunately the reduction using this system took place with high reproducibility and high yield for many different substituents (Table 1). The typical procedure followed was treatment of the suspension of the Ugi adducts 5 in ethanol with stannous chloride (10 equiv.) and hydrochloric acid solution $0.6 \mathrm{M}$ (3 equiv.). These reactions were performed at reflux with full conversion within 45 minutes.

We found several advantages in the reduction methodology chosen, such as the cost and ready availability of the reducing agent which can tolerate a variety of reducible functionalities, the high yields and short reaction times, the simple purifi- cation of products by recrystallization, the lack of need for an inert atmosphere or dry solvents as that required for the Staudinger/aza-Wittig reaction, the high efficiency of the reaction, relatively insensitive to small changes in reagents concentration or time, and the relatively easy disposal of the nontoxic residues. Additionally, this methodology was readily applicable to the synthesis of other series of benzodiazepines we were interested in.

In this way, the second family of benzodiazepines, the 4-benzoyl-4,5-dihydro-3H-benzo[e][1,4]diazepines, was synthesized by applying a similar methodology to that described above, in only two steps from the commercial products. We started from commercial 2-nitrobenzylamine 7 as the amine component containing the nitro group for further cyclization. Its reaction with phenylglyoxal 1a, alkyl isocyanide $\mathbf{4 a - b}$ and carboxylic acid $\mathbf{8 a}-\mathbf{c}$ in the typical procedure ${ }^{10}$ yielded the Ugi adducts $\mathbf{9}$. The similar characteristics of Ugi adducts $\mathbf{5}$ and $\mathbf{9}$ allowed us to apply the optimized reduction conditions for the former, yielding benzodiazepines $\mathbf{1 0}$ (Table 2). When the terephthalic acid was used as the carboxylic component, double Ugi adduct 9d and double benzodiazepine 10d were obtained with higher yields than simple Ugi adducts 9a-c and benzo- 


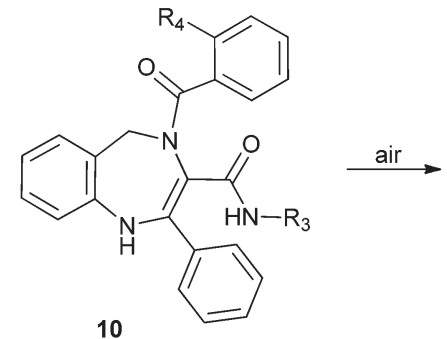

10
Scheme 1 Oxidative cleavage of 4,5-dihydro-1H-benzo[e][1,4]diazepines.

diazepines 10a-c due to their lower solubility. The high symmetry of compounds 9d and 10d simplifies their NMR spectra (see ESI $\dagger$ ).

Interestingly, the tautomer observed by NMR spectra of $\mathbf{1 0}$ was not the 4,5-dihydro-3H-benzo[e][1,4]diazepine as has been proposed for compounds of type $\mathbf{B}$ (Fig. 1$)^{6}$ but the 4,5dihydro-1H-benzo $[e][1,4]$ diazepine 10. Moreover, this tautomer underwent an oxidative cleavage on standing in $\mathrm{CDCl}_{3}$ in the presence of air (Scheme 1) as has been described for fused hydantoinbenzodiazepines, ${ }^{6}$ probably through the formation of unstable 1,2-dioxetanes generated in a [2+2] singlet oxygen addition over the double bond in the enamine. ${ }^{16}$ This means that the tautomerism is important not only for the conformation but also for the stability of these systems. Moreover, the electrophilic center on the imine tautomer is essential for the antitumor activity of some benzodiazepines as a DNA binding position. ${ }^{17}$ For these reasons it is very important to understand the effect of the presence of a carbonyl group on the benzodiazepine system.

Comparing the structure of benzodiazepines $\mathbf{6}$ and $\mathbf{1 0}$ we could establish that the presence of the oxo group at the 5 -position in the benzodiazepine nucleus is critical in the tautomeric equilibrium imine/enamine. In order to understand the observed results DFT quantum chemical calculations were carried out using Gaussian $09^{18}$ on two models, benzodiazepines $6 \mathbf{g}$ and $\mathbf{1 0 a}$. The geometries of all species were fully optimized at the B3LYP/6-31G** level.

First, we studied the stability of these benzodiazepines under neutral conditions; the calculations showed the different stability of tautomers depending on the relative position of the carbonyl group adjacent to the nitrogen at the 4-position in the benzodiazepine system. The imine tautomer in the benzo[e][1,4]diazepine-5-one $6 \mathbf{g}$ is $7.0 \mathrm{kcal} \mathrm{mol}^{-1}$ more stable than the enamine component in ethanol, whereas in the 4,5-dihydrobenzo[e][1,4]diazepine 10a the enamine is $2.3 \mathrm{kcal} \mathrm{mol}^{-1}$ more stable than the imine tautomer. However, our calculations demonstrate that the interconversion between tautomers is not possible at moderate temperatures under neutral conditions because the free energy of activation calculated for the tautomerization in both cases is too high (58.7 and $49.0 \mathrm{kcal} \mathrm{mol}^{-1}$ for $\mathbf{6} \mathbf{g}$ and $\mathbf{1 0 a}$ respectively for the tautomerization in a water-assisted process). ${ }^{19}$
Then, the experimental results should be explained as a consequence of the acidic method employed in the reduction process; otherwise, both benzodiazepines should be obtained as the same tautomer due to the high barrier of interconversion which prevents the tautomerization from the initial tautomer formed in the cyclization. Under these acidic conditions in ethanol, the benzo[e][1,4]diazepine-5-one $6 \mathrm{~g}$ is again more stable as imine than as enamine $\left(11.7 \mathrm{kcal} \mathrm{mol}^{-1}\right)$, whereas the 4,5-dihydrobenzo[e][1,4]diazepine 10a is again more stable as enamine $\left(9.6 \mathrm{kcal} \mathrm{mol}^{-1}\right)$. However, the free energies of activation calculated for each stage of the tautomerization in acid medium, protonation of imine and formation of enamine, are significantly lower in both families of compounds than the interconversion barrier under neutral conditions (Fig. 2).

For the benzo[e][1,4]diazepine-5-one $\mathbf{6} \mathbf{g}$ the activation energy decreases from $58.7 \mathrm{kcal} \mathrm{mol}^{-1}$ under neutral conditions to 26.5 and $29.0 \mathrm{kcal} \mathrm{mol}^{-1}$ in acidic medium for the protonation of imine and the enamine formation respectively (Fig. 2). These values allow us to calculate the reaction rate at each stage from the Eyring-Polanyi equation indicating that tautomerization is not possible at room temperature $\left(k_{1}=2.45\right.$ $\left.\times 10^{-7} \mathrm{~s}^{-1}, k_{2}=3.35 \times 10^{-9} \mathrm{~s}^{-1}\right)$ and it is a very slow process in boiling ethanol $\left(k_{1}=3.26 \times 10^{-3} \mathrm{~s}^{-1}, k_{2}=1.09 \times 10^{-4} \mathrm{~s}^{-1}\right)$. Additionally, the conversion of imine to enamine is thermodynamically unfavorable, especially in the second stage with an equilibrium constant of $1.57 \times 10^{-8}$. Although we have considered only one water molecule as a proton shuttle molecule and the real tautomerization barriers for $\mathbf{6}$ (as for the tautomerization in 10) could be much smaller, this would not influence the conclusions, since only the thermodynamic product 6im would be obtained. With these results in hand it is interesting to note that these benzodiazepines are then potential drug candidates, not only because of their conformation ${ }^{4}$ but also due to their stability at high temperature and under acidic conditions. $^{20}$

The behavior of 4-benzoyl-4,5-dihydrobenzo[e][1,4]diazepines $\mathbf{1 0}$ is quite different. For the benzodiazepine 10a the enamine is the most stable tautomer under acidic conditions in ethanol (thermodynamically favorable) with equilibrium constants for the conversion of imine to enamine of $1.87 \times 10^{3}$ and $6.23 \times 10^{3}$ (calculated using the Arrhenius equation), for protonation and generation of enamine respectively, and besides, the tautomeric interconversion under acidic conditions is fast at room temperature (kinetically favorable) with reaction rates of $k_{1}=6.51 \times 10^{2} \mathrm{~s}^{-1}$ and $k_{2}=5.50 \times 10^{2} \mathrm{~s}^{-1}$ for each stage, calculated from the free energies of activation in both stages (about $13.7 \mathrm{kcal} \mathrm{mol}^{-1}$, Fig. 2). The higher stability of the enamine tautomer is a problem, as these regioisomers undergo an oxidative cleavage of the double bond in the presence of oxygen (Scheme 1). Thus, in contrast with benzo[ $e][1,4]$ diazepine-5-one, these regioisomers would have several problems as pharmaceutical products due to their low stability in air.

The process of tautomerization is similar for both families of regioisomeric benzodiazepines. It starts with the protonation on the nitrogen atom of the imine groups (Scheme 2). The 


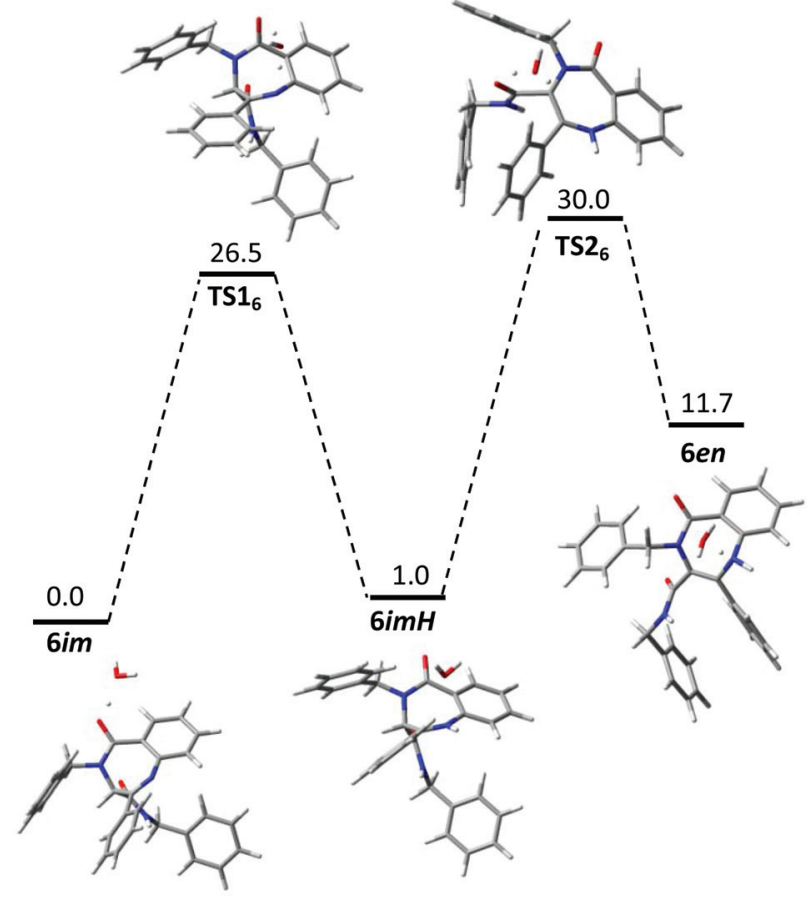

10

15

20

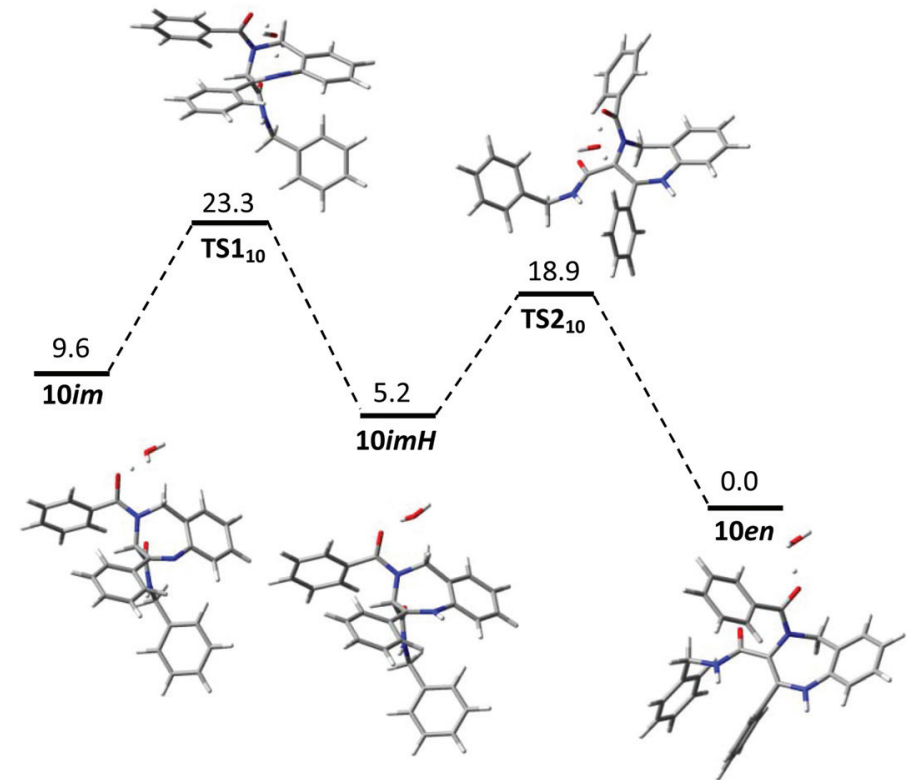

1

5

Fig. 2 Energy diagrams for the imine-enamine interconversion of $6 \mathrm{~g}$ (left) and $10 \mathrm{a}$ (right) in acidic medium. The energy values reported in the

diagram are in $\mathrm{kcal} \mathrm{mol}^{-1}$ and refer to calculations performed in ethanol.

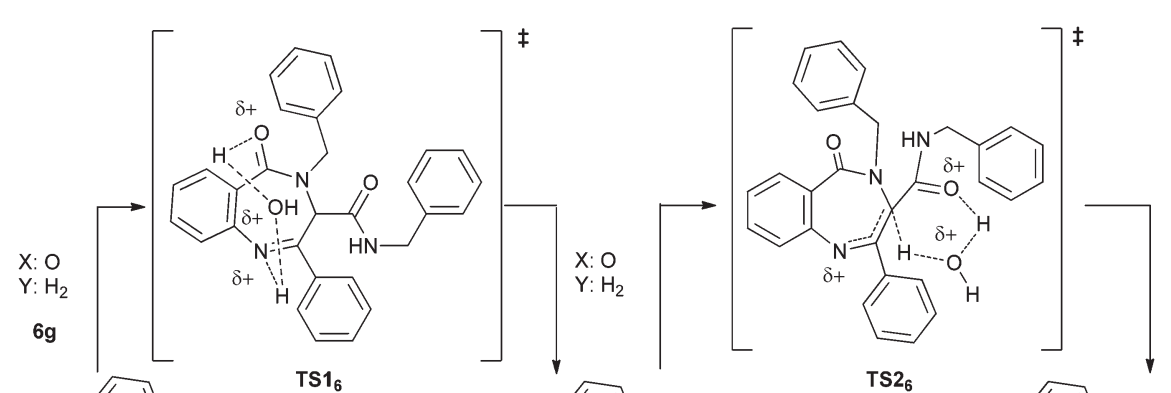

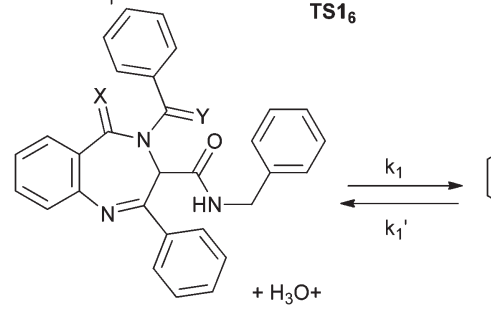
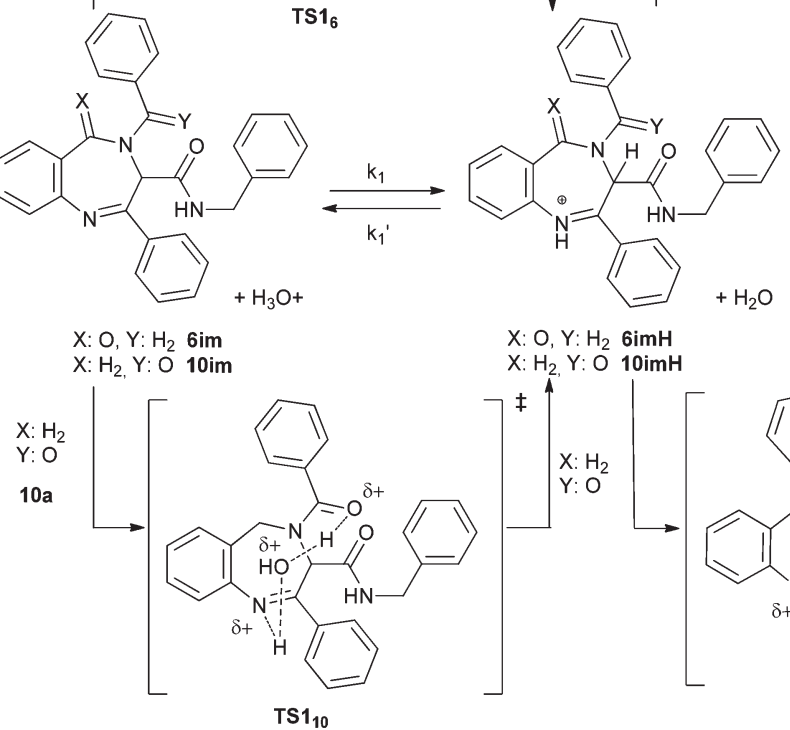

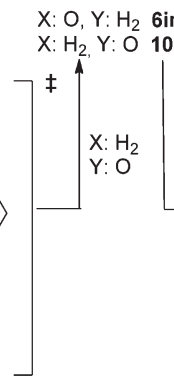

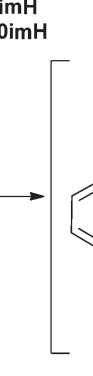
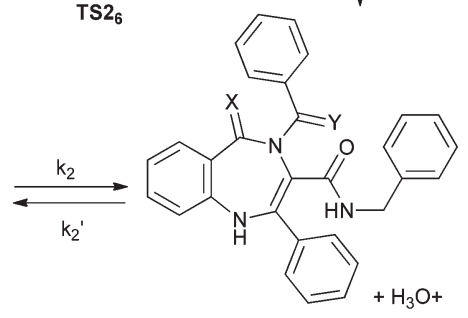

$$
X: O, Y: H_{2} \text { Gen }
$$
$X: \mathrm{H}_{2}, \mathrm{Y}: \mathrm{O}$ 10en

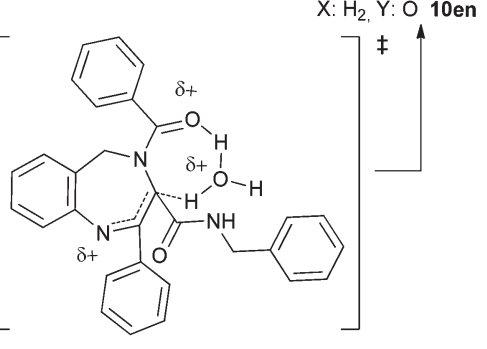

Scheme 2 Process of tautomerization for benzodiazepines $6 \mathrm{~g}$ and $10 \mathrm{a}$. 

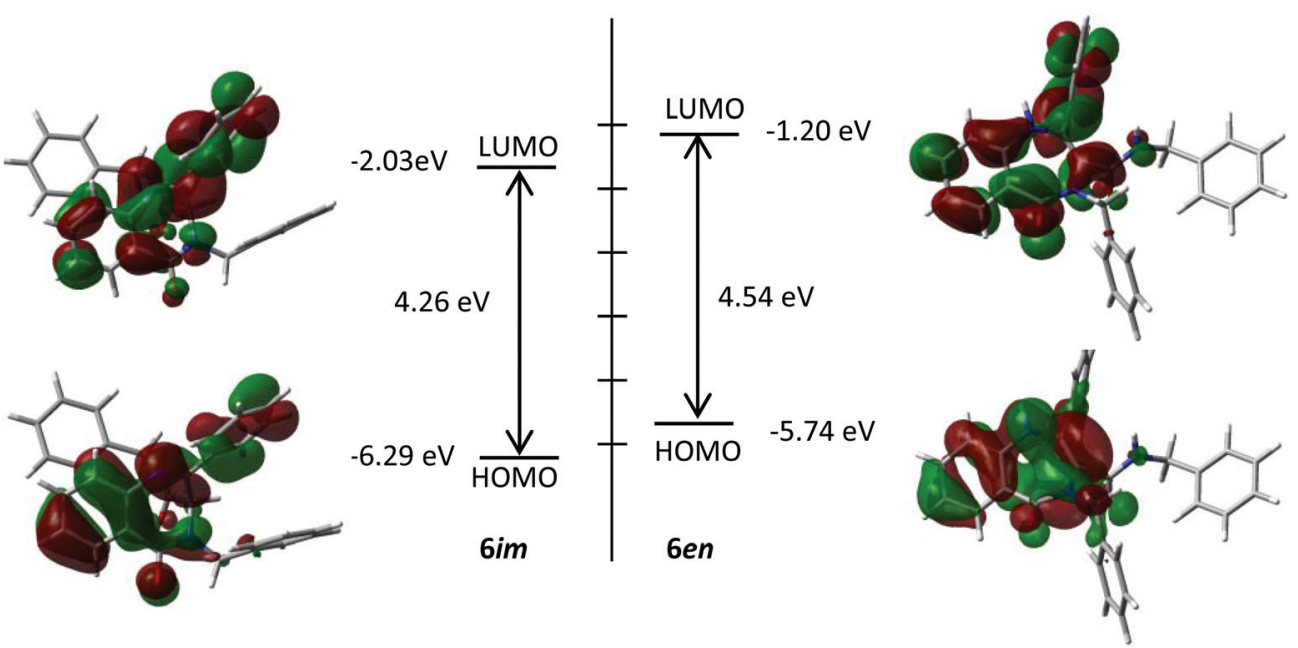

$-6.29 \mathrm{eV}$

Fig. 3 Frontier molecular orbitals surfaces of the imine (left) and enamine tautomers (right) of 6 which have been constructed by using the B3LYP/ $6-31 G^{* *}$ level of theory.

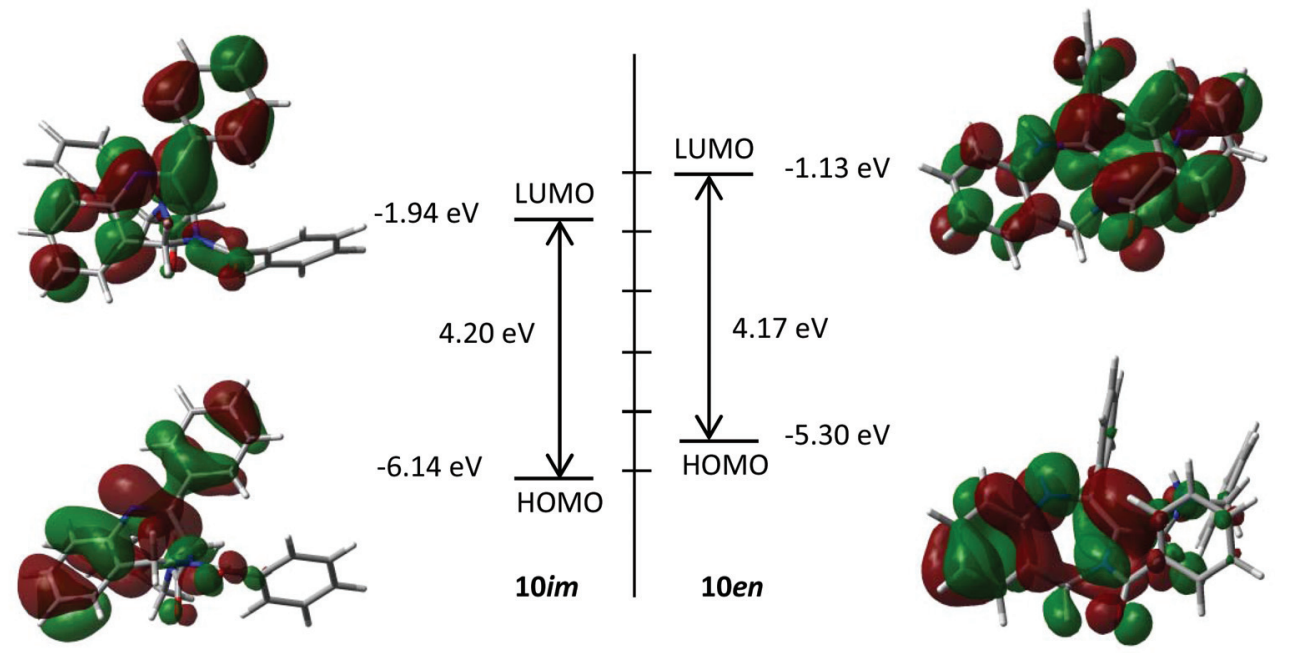

Fig. 4 Frontier molecular orbital surfaces of the imine (left) and enamine tautomers (right) of 10 which have been constructed by using the B3LYP/ $6-31 G^{* *}$ level of theory.

similar charge distribution calculated for structures 6im and 10im by NBO analysis explains the similarity between the activation complexes $\left(\mathrm{TS}_{6}\right.$ and $\mathrm{TS}_{10}$, Fig. 2) found in the first stage.

However the second stage seems to be dependent on the regioisomer under study. This is supported by the fact that the NBO analysis of 10imH reveals a more negative charge in the oxygen of the carbonyl group adjacent to the nitrogen at the 4-position in the 1,4-diazepine ring $(-0.66 e)$ than in the oxygen of the 3-aminocarbonyl substituent $(-0.63 e)$. This difference favors the participation of the former group in a seven-member ring transition state $\mathbf{T S} 2_{10}$ in which a molecule of water acts as a "hydrogen bridge".

The electronic distribution of the HOMO of the imine tautomers depends on the presence of the oxo group in the benzodiazepine ring, the HOMO in 6im is delocalized along the benzodiazepine system from the amide group to the benzene ring and the $\mathrm{C}=\mathrm{N} \pi$-bonding, whereas in 10im it is mainly localized on $\mathrm{C}=\mathrm{N} \pi$-bonding and the benzene ring. The HOMO surfaces for the enamine tautomers $6 \boldsymbol{e n}$ and 10en are similarly delocalized over the $\mathrm{C}=\mathrm{C} \pi$-bonding and the benzene ring. The HOMO-LUMO gap is similar for all the tautomers (Fig. 3 and 4).

The calculated bond lengths reveal some differences between tautomers of benzo[e][1,4]diazepine-5-ones 6 and 4,5dihydrobenzo[ $[e][1,4]$ diazepines 10. The $\mathrm{C}^{2}=\mathrm{N}^{1}$ bonds in the imine tautomers 6im and 10im have similar lengths and the $\mathrm{N}^{1}-\mathrm{C}^{7}$ and $\mathrm{C}^{5}-\mathrm{C}^{6}$ bonds are slightly shorter in $6 \mathrm{im}$. This difference can be explained by the conjugation between the imine and the amide group through the benzene ring only possible in benzodiazepines 6 . In the enamine forms, the $\mathrm{C}^{2}-\mathrm{N}^{1}$ bond is much shorter in 10en than in 6en due in this case to the 

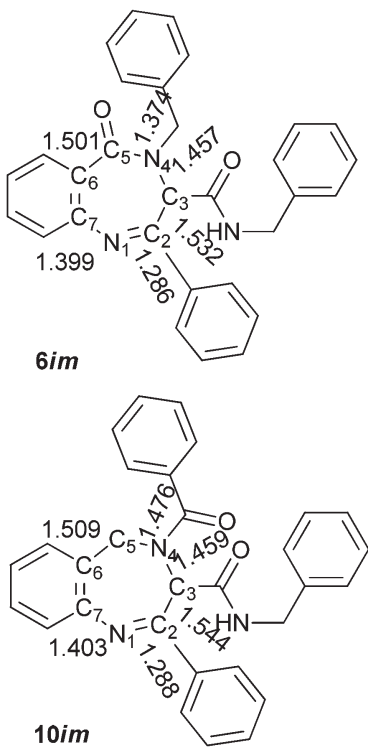

$6 e n$

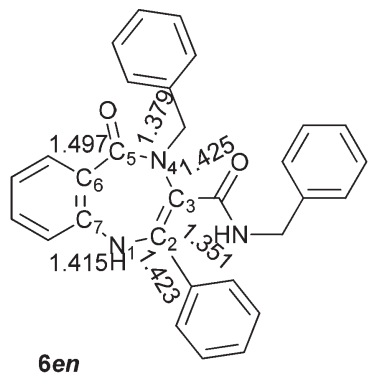

Fig. 5 Relevant bond lengths in the diazepine system calculated at the B3LYP/6-31G** level of theory.

more favored conjugation with the carboxamide group in 3-position through the double bond $\mathrm{C}^{2}=\mathrm{C}^{3}$ of the enamine (Fig. 5).

\section{Conclusions}

In summary, we have developed a simple and scalable methodology for the synthesis of regioisomeric pseudopeptidic benzodiazepines from economical and available reagents in only two steps. The tautomerism present in the 1,4-benzodiazepines is crucial to understand the different behaviors of 4-benzyl-3Hbenzo[e][1,4]diazepin-5(4H)-ones and 4-benzoyl-4,5-dihydro$3 H$-benzo $[e][1,4]$ diazepines in acidic medium, their conformation and stability as well as to evaluate their potential use as drug candidates. The experimental results have been confirmed by DFT quantum calculations at the B3LYP/6-31G** level of theory.

\section{Experimental section}

\section{General information}

Melting points are not corrected. Infrared spectra were registered in potassium bromide tablets. ${ }^{1} \mathrm{H}$ and ${ }^{13} \mathrm{C}$ NMR spectra were recorded in $\mathrm{CDCl}_{3}$ and DMSO- $d_{6}$ at 400 and $100 \mathrm{MHz}$ or at 300 and $75 \mathrm{MHz}$ on a Varian Inova 400 or a Varian Mercury 300 , respectively. Chemical shifts are reported in parts per million with respect to residual solvent protons, and coupling constants are reported in hertz. Low resolution mass spectra and HRMS were recorded in the positive ion mode by electronic impact at $70 \mathrm{eV}$.
General procedure for the synthesis of Ugi adducts $5 a-j$

1

A solution of arylglyoxal $\mathbf{1 a}-\mathbf{b}(1 \mathrm{mmol})$ and substituted benzylamine $2 \mathbf{a}-\mathbf{e}(1 \mathrm{mmol})$ in methanol was stirred for $15 \mathrm{~min}$ at room temperature. Then, 2-nitrobenzoic acid 3 (0.167 g, $1 \mathrm{mmol})$ and isocyanide $\mathbf{4 a}-\mathbf{b}(1 \mathrm{mmol})$ were added and the mixture was stirred for 1 day until a solid precipitated. The solid was filtered and recrystallized from i-PrOH-i- $\mathrm{Pr}_{2} \mathrm{O}$.

(E)- $N$-Cyclohexyl-2-[ $N$-benzyl- $N$-(2-nitrobenzoyl)amino]-3hydroxy-3-phenylacrylamide 5a. White solid, m.p. 192-193 ${ }^{\circ} \mathrm{C}$. (conformational isomers $E 1 / E 2: 77 / 23) .{ }^{4} \mathrm{IR}\left(\mathrm{KBr}, \mathrm{cm}^{-1}\right): 3418$ $(\mathrm{OH}), 2937,2855,1651(\mathrm{C}=\mathrm{O}), 1538,1350 .{ }^{1} \mathrm{H}$ NMR $(300 \mathrm{MHz}$, $\left.\mathrm{CDCl}_{3}\right) \delta: 15.97(\mathrm{~s}, 0.23 \mathrm{H}, \mathrm{OH} E 2), 15.36(\mathrm{~s}, 0.77 \mathrm{H}, \mathrm{OH} E 1)$, 8.35-6.80 (m, 13H, $\left.\mathrm{H}_{\mathrm{Ar}} E 1 / E 2\right), 6.36(\mathrm{~d}, J=8.1 \mathrm{~Hz}, 0.77 \mathrm{H}, \mathrm{NH}$ $E 1), 5.87$ (d, $J=8.1 \mathrm{~Hz}, 0.23 \mathrm{H}, \mathrm{NH} E 2), 5.86$ (d, $J=13.6 \mathrm{~Hz}$, $0.23 \mathrm{H}, \mathrm{CH}_{2}$ benz E2), 4.12 (d, $J=13.8 \mathrm{~Hz}, 0.77 \mathrm{H}, \mathrm{CH}_{2}$ benz $\left.E 1\right)$, 3.77 (d, $J=13.8 \mathrm{~Hz}, 0.77 \mathrm{H}, \mathrm{CH}_{2}$ benz $\left.E 1\right), 3.62$ (d, $J=13.6 \mathrm{~Hz}$, $023 \mathrm{H}, \mathrm{CH}_{2}$ benz E2), 3.70-3.55 (m, 0.77H, CH E1), 3.25-3.10 $(\mathrm{m}, 0.23 \mathrm{H}, \mathrm{CH} E 2), 2.05-0.30(\mathrm{~m}, 10 \mathrm{H}, E 1 / E 2) .{ }^{13} \mathrm{C} \mathrm{NMR}$ $\left(75 \mathrm{MHz}, \mathrm{CDCl}_{3}\right) \delta: 171.4,169.0,168.5,168.4,145.5$ (Cq E1/E2), $135.0\left(\mathrm{CH}_{\mathrm{Ar}}\right), 133.7(\mathrm{Cq} E 1 / E 2), 133.5\left(\mathrm{CH}_{\mathrm{Ar}}\right), 132.0(\mathrm{Cq}), 131.6$, $130.6,130.5$, 130.4, 130.2, 130.1, 129.4, 129.3, 128.8, 128.7, 128.1, 127.9, 127.7, 127.6, 125.6, $125.1\left(\mathrm{CH}_{\mathrm{Ar}} E 1 / E 2\right), 105.1$ (Cq), $56.2\left(\mathrm{CH}_{2}\right), 54.0\left(\mathrm{CH}_{2}\right), 49.0(\mathrm{CH}), 48.7(\mathrm{CH}), 32.8\left(\mathrm{CH}_{2}\right)$, $32.7\left(\mathrm{CH}_{2}\right), 32.0\left(\mathrm{CH}_{2}\right), 31.8\left(\mathrm{CH}_{2}\right), 25.6\left(\mathrm{CH}_{2}\right), 25.4\left(\mathrm{CH}_{2}\right), 25.2$ $\left(\mathrm{CH}_{2}\right), 25.2\left(\mathrm{CH}_{2}\right)$. MS (EI) $\mathrm{m} / z$ (relative intensity): $499\left(\mathbf{M}^{+}, 5\right)$; 349 (20); 224 (10); 150 (53); 105 (49); 91 (100); 77 (19). HRMS (EI): calcd for $\mathrm{C}_{29} \mathrm{H}_{29} \mathrm{~N}_{3} \mathrm{O}_{5}\left[\mathrm{M}^{+}\right] 499.2107$ found 499.2094.

$(E)-N$-Cyclohexyl-2-[ $N$-(4-methylbenzyl)- $N$-(2-nitrobenzoyl)amino]-3-hydroxy-3-phenylacrylamide $5 \mathbf{b}$. White solid, m.p. 185-186 ${ }^{\circ} \mathrm{C}$ (conformational isomers E1/E2: 63/37). IR (KBr, $\left.\mathrm{cm}^{-1}\right)$ : $3425(\mathrm{OH}), 2928,2856,1651(\mathrm{C}=\mathrm{O}), 1538,1349 .{ }^{1} \mathrm{H}$ NMR (300 MHz, $\mathrm{CDCl}_{3}$ ) $\delta: 15.96$ (s, 0.37H, OH E2), 15.37 (s, $0.63 \mathrm{H}, \mathrm{OH} E 1), 8.33-6.66\left(\mathrm{~m}, 13 \mathrm{H}, \mathrm{H}_{\mathrm{Ar}} E 1 / E 2\right), 6.33$ (d, $J=8.3$ $\mathrm{Hz}, 0.63 \mathrm{H}, \mathrm{NH} E 1), 5.89$ (d, $J=13.9 \mathrm{~Hz}, 0.37 \mathrm{H}, \mathrm{CH}_{2}$ benz $E 2$ ), 5.82 (d, $J=8.3 \mathrm{~Hz}, 0.37 \mathrm{H}, \mathrm{NH} E 1), 4.08$ (d, $J=13.9 \mathrm{~Hz}, 0.63 \mathrm{H}$, $\mathrm{CH}_{2}$ benz $E 1$ ), 3.73 (d, $J=13.9 \mathrm{~Hz}, 0.63 \mathrm{H}, \mathrm{CH}_{2}$ benz $E 1$ ), 3.58 (d, $J=13.9 \mathrm{~Hz}, 0.37 \mathrm{H}, \mathrm{CH}_{2}$ benz E2), 3.70-3.60 (m, 0.63H, $\mathrm{CH}$ $E 1), 3.30-3.06$ (m, 0.37H, CH E2), 2.33 (s, $\left.1.11 \mathrm{H}, \mathrm{CH}_{3} E 2\right), 2.28$ (s, 1.89H, $\left.\mathrm{CH}_{3} E 1\right), 2.02-0.21(\mathrm{~m}, 10 \mathrm{H}, E 1 / E 2) .{ }^{13} \mathrm{C} \mathrm{NMR}$ $\left(75 \mathrm{MHz}, \mathrm{CDCl}_{3}\right) \delta: 171.3,169.0,168.3,145.4,138.5$ (Cq E1/E2), $135.1\left(\mathrm{CH}_{\mathrm{Ar}}\right), 134.5(\mathrm{Cq}), 133.5\left(\mathrm{CH}_{\mathrm{Ar}}\right), 133.4(\mathrm{Cq}), 131.6,130.6$, $130.5,130.4$, 130.1, 130.0, 129.4, 128.6, 128.1, 127.9, 127.7, 127.6, 125.6, $125.1\left(\mathrm{CH}_{\mathrm{Ar}} E 1 / E 2\right), 105.0(\mathrm{Cq}), 55.9\left(\mathrm{CH}_{2}\right), 53.7$ $\left(\mathrm{CH}_{2}\right), 48.9(\mathrm{CH}), 48.7(\mathrm{CH}), 32.8\left(\mathrm{CH}_{2}\right), 32.7\left(\mathrm{CH}_{2}\right), 31.9\left(\mathrm{CH}_{2}\right)$, $31.8\left(\mathrm{CH}_{2}\right), 25.6\left(\mathrm{CH}_{2}\right), 25.5\left(\mathrm{CH}_{2}\right), 25.4\left(\mathrm{CH}_{2}\right), 25.3\left(\mathrm{CH}_{2}\right), 25.2$ $\left(\mathrm{CH}_{2}\right), 21.4\left(\mathrm{CH}_{3}\right) . \mathrm{MS}$ (EI) $\mathrm{m} / z$ (relative intensity): $513\left(\mathrm{M}^{+}, 4\right)$; 363 (16); 269 (9); 150 (71); 105 (100); 77 (13). HRMS (EI): calcd for $\mathrm{C}_{30} \mathrm{H}_{31} \mathrm{~N}_{3} \mathrm{O}_{5}\left[\mathrm{M}^{+}\right] 513.2264$ found 513.2258.

(E)-N-Cyclohexyl-2-[N-(4-methoxylbenzyl)- $N$-(2-nitrobenzoyl)amino]-3-hydroxy-3-phenylacrylamide 5c. White solid, m.p. 192-193 ${ }^{\circ} \mathrm{C}$ (conformational isomers E1/E2: 57/43). IR ( $\mathrm{KBr}$, $\left.\mathrm{cm}^{-1}\right)$ : $3425(\mathrm{NH}), 2937,2855,1651(\mathrm{C}=\mathrm{O}), 1538,1351 .{ }^{1} \mathrm{H}$ NMR (300 MHz, $\mathrm{CDCl}_{3}$ ) $\delta: 15.95$ (s, 0.43H, OH E2), 15.37 (s, $0.57 \mathrm{H}, \mathrm{OH} E 1), 8.33-6.63\left(\mathrm{~m}, 13 \mathrm{H}, \mathrm{H}_{\mathrm{Ar}} E 1 / E 2\right), 6.36$ (d, $J=7.9$ $\mathrm{Hz}, 0.57 \mathrm{H}, \mathrm{NH} E 1), 5.86$ (d, $J=7.9 \mathrm{~Hz}, 0.43 \mathrm{H}, \mathrm{NH} E 2), 5.80$ (d, 
$J=13.7 \mathrm{~Hz}, 0.43 \mathrm{H}, \mathrm{CH}_{2}$ benz E2), $4.07(\mathrm{~d}, J=13.9 \mathrm{~Hz}, 0.57 \mathrm{H}$, $\mathrm{CH}_{2}$ benz E1), 3.79 (s, $\left.1.3 \mathrm{H}, \mathrm{CH}_{3} E 2\right), 3.76$ (s, $\left.1.7 \mathrm{H}, \mathrm{CH}_{3} E 1\right)$, $3.73\left(\mathrm{~d}, J=13.9 \mathrm{~Hz}, 0.57 \mathrm{H}, \mathrm{CH}_{2}\right.$ benz $\left.E 1\right), 3.69-3.62(\mathrm{~m}, 0.43 \mathrm{H}$, $\mathrm{CH} E 2), 3.58$ (d, $J=13.7 \mathrm{~Hz}, 0.43 \mathrm{H}, \mathrm{CH}_{2}$ benz $E 2$ ), 3.31-3.16 (m, 0.57H, CH E1), 2.10-0.27 (m, 10H, E1/E2). ${ }^{13} \mathrm{C}$ NMR $\left(75 \mathrm{MHz}, \mathrm{CDCl}_{3}\right) \delta: 171.3,169.5,169.0,168.4,168.3,168.1$, $160.0,159.8,146.7,145.4$ (Cq $E 1 / E 2$ ), 135.1, 135.0, 133.8, $133.6,133.5,132.0,131.6,131.4,131.3,130.6,130.5,130.4$, $129.4,128.8,128.7,128.5,128.1,127.9,127.7,127.6,125.7$, 125.6, 125.1, 114.7, $114.1\left(\mathrm{CH}_{\mathrm{Ar}} E 1 / E 2\right), 107.9,104.9$ (Cq E1/ E2), $55.5\left(\mathrm{CH}_{2}\right), 53.3\left(\mathrm{CH}_{3}\right), 49.3,48.9,48.7$ ( $\mathrm{CH} \mathrm{E1/E2),} \mathrm{32.8,}$ 32.0, 32.0, 25.7, 25.6, 25.4, $25.2\left(\mathrm{CH}_{2} E 1 / E 2\right)$. MS (EI) $\mathrm{m} / z$ (relative intensity): 529 ( $\left.\mathrm{M}^{+}, 4.4\right), 408$ (9), 285 (14), 150 (45), 121 (100), 105 (22). HRMS (EI): calcd for $\mathrm{C}_{30} \mathrm{H}_{31} \mathrm{~N}_{3} \mathrm{O}_{6}\left[\mathrm{M}^{+}\right] 529.2213$ found 529.2208.

(E)- $N$-Cyclohexyl-2-[N-(4-fluorobenzyl)- $N$-(2-nitrobenzoyl)amino]-3-hydroxy-3-phenylacrylamide 5d. White solid, m.p. 182-183 ${ }^{\circ} \mathrm{C}$ (conformational isomers $E 1 / E 2$ : 56/44). IR ( $\mathrm{KBr}$, $\left.\mathrm{cm}^{-1}\right)$ : $3419(\mathrm{OH}), 2927,2855,1651(\mathrm{C}=\mathrm{O}), 1530,1347 .{ }^{1} \mathrm{H}$ NMR (400 MHz, $\mathrm{CDCl}_{3}$ ) $\delta: 15.98$ (s, 0.44H, OH E2), 15.37 (s, $0.56 \mathrm{H}, \mathrm{OH} E 1), 8.30-6.71\left(\mathrm{~m}, 13 \mathrm{H}, \mathrm{H}_{\mathrm{Ar}}, E 1 / E 2\right), 6.36$ (d, $J=7.9$ $\mathrm{Hz}, 0.56 \mathrm{H}, \mathrm{NH} E 1), 5.89$ (d, $J=7.9 \mathrm{~Hz}, 0.44 \mathrm{H}, \mathrm{NH} E 2), 5.76$ (d, $J=13.9 \mathrm{~Hz}, 0.44 \mathrm{H}, \mathrm{CH}_{2}$ benz $\left.E 2\right), 4.08(\mathrm{~d}, J=13.9 \mathrm{~Hz}, 0.56 \mathrm{H}$, $\mathrm{CH}_{2}$ benz E1), 3.77 (d, $J=13.9 \mathrm{~Hz}, 0.56 \mathrm{H}, \mathrm{CH}_{2}$ benz $E 1$ ), 3.74-3.63 (m, 0.44H, CH E2), 3.58 (d, $J=13.9 \mathrm{~Hz}, 0.44 \mathrm{H}, \mathrm{CH}_{2}$ benz E2), 3.30-3.19 (m, 0.56H, CH E1), 2.05-0.26 (m, 10H, E1/ $E 2) .{ }^{13} \mathrm{C}$ NMR $\left(100 \mathrm{MHz}, \mathrm{CDCl}_{3}\right) \delta: 171.7,171.6,169.4,169.0$, 168.6, 168.3 (Cq E1/E2), 163.1 (d, ${ }^{1} J=247.8 \mathrm{~Hz}$ ), 162.9 (d, ${ }^{1} J=$ $247.8 \mathrm{~Hz}, E 1 / E 2), 146.9,145.5,135.2$ (Cq E1/E2), $135.1\left(\mathrm{CH}_{\mathrm{Ar}}\right)$, 134.9, 134.8, 133.7 (Cq E1/E2), $133.5\left(\mathrm{CH}_{\mathrm{Ar}}\right), 133.4,133.4,132.6$ (Cq E1/E2), 132.0, 131.8, 131.7, 131.3, 130.6, 130.5, 129.6, $128.9,128.6,128.2,127.9,127.7,127.6,125.6,125.1\left(\mathrm{CH}_{\mathrm{Ar}} E 1 /\right.$ $E 2), 116.0\left(\mathrm{~d},{ }^{2} J=21.5 \mathrm{~Hz}\right), 115.8\left(\mathrm{~d},{ }^{2} J=21.5 \mathrm{~Hz}, \mathrm{CH}_{\mathrm{Ar}} E 1 / E 2\right)$, $107.8,104.7$ (Cq E1/E2), 55.2, 53.2 ( $\left.\mathrm{CH}_{2} E 1 / E 2\right), 49.0,48.7(\mathrm{CH}$ $E 1 / E 2), 32.8,32.1,32.0,25.7,25.6,25.4,25.3,25.2,24.9,24.9$ $\left(\mathrm{CH}_{2} \mathrm{E1} / \mathrm{E2}\right)$. MS (EI) $\mathrm{m} / \mathrm{z}$ (relative intensity): $517\left(\mathrm{M}^{+}, 4.6\right), 367$ (13), 150 (87), 109 (100), 105 (54). HRMS (EI): calcd for $\mathrm{C}_{29} \mathrm{H}_{28} \mathrm{FN}_{3} \mathrm{O}_{5}\left[\mathrm{M}^{+}\right] 517.2013$ found 517.2002.

(E)- $N$-Cyclohexyl-2-[N-(4-chlorobenzyl)- $N$-(2-nitrobenzoyl)amino]-3-hydroxy-3-phenylacrylamide 5e. White solid, m.p. 197-198 ${ }^{\circ} \mathrm{C}$ (conformational isomers E1/E2: 55/45). IR ( $\mathrm{KBr}$, $\left.\mathrm{cm}^{-1}\right)$ : $3424(\mathrm{OH}), 2930,2857,1651(\mathrm{C}=\mathrm{O}), 1538,1350$. ${ }^{1} \mathrm{H}$ NMR (300 MHz, $\mathrm{CDCl}_{3}$ ) $\delta: 16.00$ (s, 0.45H, OH E2), 15.40 (s, $0.55 \mathrm{H}, \mathrm{OH} E 1), 8.30-6.71\left(\mathrm{~m}, 13 \mathrm{H}, \mathrm{H}_{\mathrm{Ar}}, E 1 / E 2\right), 6.38$ (d, $J=8.3$ $\mathrm{Hz}, 0.55 \mathrm{H}, \mathrm{NH} E 1$ ), 5.92 (d, $J=8.3 \mathrm{~Hz}, 0.45 \mathrm{H}, \mathrm{NH} E 2), 5.81$ (d, $J=13.9 \mathrm{~Hz}, 0.45 \mathrm{H}, \mathrm{CH}_{2}$ benz E2), $4.09(\mathrm{~d}, J=13.9 \mathrm{~Hz}, 0.55 \mathrm{H}$, $\mathrm{CH}_{2}$ benz E1), 3.79 (d, $J=13.9 \mathrm{~Hz}, 0.55 \mathrm{H}, \mathrm{CH}_{2}$ benz $E 1$ ), 3.75-3.72 (m, 0.45H, CH E2), 3.57 (d, $J=13.9 \mathrm{~Hz}, 0.45 \mathrm{H}, \mathrm{CH}_{2}$ benz E2), 3.34-3.14 (m, 0.55H, CH E1), 2.10-0.90 (m, $10 \mathrm{H})$. ${ }^{13} \mathrm{C}$ NMR $\left(75 \mathrm{MHz}, \mathrm{CDCl}_{3}\right) \delta: 171.2,169.4,168.9,168.6,168.4$, 168.1, 146.8, 145.5 (Cq $E 1 / E 2), 135.2,134.8,133.6,133.3$, $132.1,131.7,131.6,131,3,130.7,130.6,130.5,129.5,129.4$, 128.9, 128.6, 128.1, 127.9, 127.7, 127.5, 125.7, $125.2\left(\mathrm{CH}_{\mathrm{Ar}}\right)$, $107.7,104.5$ (Cq E1/E2), 55,3, $53.3\left(\mathrm{CH}_{2} E 1 / E 2\right), 49.0,48.7(\mathrm{CH}$ $E 1 / E 2), 32,9,32.1,32.0,25.6,25.4,25.3,25.3,25.2\left(\mathrm{CH}_{2} E 1 / E 2\right)$. MS (EI) $m / z$ (relative intensity): $533\left(\mathbf{M}^{+}, 27\right), 535\left(\mathbf{M}^{+}+2,10\right)$,
408 (16), 410 (13), 383 (100), 288 (39), 245 (44), 150 (83), 125 (74), 105 (51). HRMS (EI): calcd for $\mathrm{C}_{29} \mathrm{H}_{28} \mathrm{ClN}_{3} \mathrm{O}_{5}\left[\mathrm{M}^{+}\right]$ 533.1717 found 533.1717 .

$(E)-N$-Cyclohexyl-2-[ $N$-benzyl- $N$-(2-nitrobenzoyl)amino]-3hydroxy-3-(4-fluoro)phenylacrylamide 5 f. White solid, m.p. 154-155 ${ }^{\circ} \mathrm{C}$ (conformational isomers $E 1 / E 2$ : 63/37). IR ( $\mathrm{KBr}$, $\left.\mathrm{cm}^{-1}\right)$ : $3422(\mathrm{OH}), 2928,2855,1651(\mathrm{C}=\mathrm{O}), 1538,1403,1349$. ${ }^{1} \mathrm{H} \mathrm{NMR}\left(300 \mathrm{MHz}, \mathrm{CDCl}_{3}\right.$ ) $\delta: 16.08$ (s, 0.37H, OH E2), 15.42 (s, $0.63 \mathrm{H}, \mathrm{OH} E 1), 8.42-6.75\left(\mathrm{~m}, 13 \mathrm{H}, \mathrm{H}_{\mathrm{Ar}} E 1 / E 2\right), 6.46$ (d, $J=7.9$ $\mathrm{Hz}, 0.63 \mathrm{H}, \mathrm{NH} E 1$ ), 5.88 (d, $J=7.9 \mathrm{~Hz}, 0.37 \mathrm{H}, \mathrm{NH} E 2), 5.85$ (d, $J=13.9 \mathrm{~Hz}, 0.37 \mathrm{H}, \mathrm{CH}_{2}$ benz $\left.E 2\right), 4.13(\mathrm{~d}, J=13.9 \mathrm{~Hz}, 0.63 \mathrm{H}$, $\mathrm{CH}_{2}$ benz E1), 3.87 (d, $J=13.9 \mathrm{~Hz}, 0.63 \mathrm{H}, \mathrm{CH}_{2}$ benz $E 1$ ), 3.76-3.65 (m, 0.63H, CH E2), 3.62 (d, $J=13.9 \mathrm{~Hz}, 0.37 \mathrm{H}, \mathrm{CH}_{2}$ benz E2), 3.27-3.09 (m, 0.37H, CH E2), 2.05-0.26 (m, 10H, E1/ E2). ${ }^{13} \mathrm{C} \mathrm{NMR}\left(75 \mathrm{MHz}, \mathrm{CDCl}_{3}\right) \delta: 170.7,169.4,168.8,168.6$, $167.4(\mathrm{Cq} E 1 / E 2), 164.0$ (d, $\left.{ }^{1} J=250.4 \mathrm{~Hz}, \mathrm{Cq} E 1 / E 2\right), 145.4(\mathrm{Cq}$ $E 1 / E 2), 135.2$, 133.6, 133.5, 133.5, 133.4, 130.7, 130.5, 130.2, 130.0, 129.8, 129.7, 129.4, 128.8, 128.7, 127.7, 127.6, 116.3 (d, $\left.{ }^{2} J=21.5 \mathrm{~Hz}\right), 116.0\left(\mathrm{~d},{ }^{2} J=21.5 \mathrm{~Hz}, \mathrm{CH}_{\mathrm{Ar}} E 1 / E 2\right), 107.6,104.7$ (Cq $E 1 / E 2), 56.0,53.9\left(\mathrm{CH}_{2} E 1 / E 2\right), 49.1,48.7$ (CH E1/E2), 32.8, 32.8, 32.0, 31.8, 25.6, 25.4, 25.4, 25.3, 25.2, $25.2\left(\mathrm{CH}_{2} E 1 / E 2\right)$. MS (EI) $m / z$ (relative intensity): 517 ( $\left.\mathbf{M}^{+}, 4\right) ; 367$ (20); 278 (22); 277 (31); 150 (53); 123 (50); 98 (25); 91 (100). HRMS (EI): calcd for $\mathrm{C}_{29} \mathrm{H}_{28} \mathrm{~N}_{3} \mathrm{O}_{5} \mathrm{~F}\left[\mathrm{M}^{+}\right] 517.2013$ found 517.2009.

(E)- $N$-Benzyl-2-[ $N$-benzyl- $N$-(2-nitrobenzoyl)amino]-3hydroxy-3-phenylacrylamide 5g. White solid, m.p. $148-149{ }^{\circ} \mathrm{C}$ (conformational isomers E1/E2: 58/42). IR $\left(\mathrm{KBr}, \mathrm{cm}^{-1}\right): 3427$ $(\mathrm{OH}), 3064\left(\mathrm{C}_{\mathrm{Ar}}\right), 3032,2923,1651(\mathrm{C}=\mathrm{O}), 1529,1402,1346 .{ }^{1} \mathrm{H}$ NMR (300 MHz, $\mathrm{CDCl}_{3}$ ) $\delta: 15.76(\mathrm{~s}, 0.42 \mathrm{H}, \mathrm{OH} E 2), 15.13$ (s, $0.58 \mathrm{H}, \mathrm{OH} E 1), 8.31-6.70\left(\mathrm{~m}, 19 \mathrm{H}, \mathrm{H}_{\mathrm{Ar}}, E 1 / E 2\right), 7.02-6.94(\mathrm{~m}$, $0.58 \mathrm{H}, \mathrm{NH} E 1), 6.51-6.39$ (m, 0.42H, NH E2), 5.80 (d, $J=13.6$ $\mathrm{Hz}, 0.42 \mathrm{H}, \mathrm{CH}_{2}$ benz E2), 4.49 (dd, $J=15.0,6.0 \mathrm{~Hz}, 0.58 \mathrm{H}, \mathrm{CH}_{2}$ benz E1), 4.39 (dd, $J=15.0,6.0 \mathrm{~Hz}, 0.58 \mathrm{H}, \mathrm{CH}_{2}$ benz $E 1$ ), 4.11 (d, $J=13.8 \mathrm{~Hz}, 0.58 \mathrm{H}, \mathrm{CH}_{2}$ benz $E 1$ ), 4.07 (dd, $J=14.5,5.5 \mathrm{~Hz}$, $0.42 \mathrm{H}, \mathrm{CH}_{2}$ benz E2), 3.81(d, $J=13.8 \mathrm{~Hz}, 0.58 \mathrm{H}, \mathrm{CH}_{2}$ benz $E 1$ ), 3.62 (d, $J=13.6 \mathrm{~Hz}, 0.42 \mathrm{H}, \mathrm{CH}_{2}$ benz $E 2$ ), 3.55 (dd, $J=14.5,5.5$ $\mathrm{Hz}, 0.42 \mathrm{H}, \mathrm{CH}_{2}$ benz E2). ${ }^{13} \mathrm{C} \mathrm{NMR}\left(75 \mathrm{MHz}, \mathrm{CDCl}_{3}\right) \delta: 171.6$, $170.2,170.0,168.5,146.8,145.5,137.9,137.2,136.1$ (Cq E1/ E2), 135.1, 134.8, 133.4, 133.3, 131.8, 130.7, 130.6, 130.2, 130.1, $129.9,129.5,128.8,128.7,128.2$, 128.1, 128.0, 127.6, 127.4, 125.6, 125.4 $\left(\mathrm{CH}_{\mathrm{Ar}} E 1 / E 2\right), 107.6,105.0$ (Cq E1/E2), 56.1, 53.6, 43.4, $43.1\left(\mathrm{CH}_{2} E 1 / E 2\right)$. MS (EI) $m / z$ (relative intensity): $507\left(\mathrm{M}^{+}\right.$, 6.6), 357 (17), 150 (43), 91 (100). HRMS (EI): calcd for $\mathrm{C}_{30} \mathrm{H}_{25} \mathrm{~N}_{3} \mathrm{O}_{5}\left[\mathrm{M}^{+}\right] 507.1794$ found 507.1796.

$(E)-N$-Benzyl-2-[ $N$-(4-methylbenzyl)- $N$-(2-nitrobenzoyl) amino]3-hydroxy-3-phenylacrylamide $5 \mathrm{~h}$. White solid, m.p. 144-145 ${ }^{\circ} \mathrm{C}$ (conformational isomers $E 1 / E 2$ : 64/36). IR ( $\mathrm{KBr}$, $\left.\mathrm{cm}^{-1}\right)$ : $3441(\mathrm{OH}), 3065\left(\mathrm{C}_{\mathrm{Ar}}\right), 3031,2934,2859,1651(\mathrm{C}=\mathrm{O})$, 1393, 1348. ${ }^{1} \mathrm{H}$ NMR (300 MHz, $\left.\mathrm{CDCl}_{3}\right) \delta: 15.71(\mathrm{~s}, 0.36 \mathrm{H}, \mathrm{OH}$ $E 2), 15.09$ (s, 0.64H, OH E1), 8.29-6.52 (m, $\left.18 \mathrm{H}, \mathrm{H}_{\mathrm{Ar}}, E 1 / E 2\right)$, 7.03-6.95 (m, 0.64H, NH E1), 6.51-6.39 (m, 0.36H, NH E2), 5.77 (d, $J=13.5 \mathrm{~Hz}, 0.36 \mathrm{H}, \mathrm{CH}_{2}$ benz $\left.E 2\right), 4.49$ (dd, $J=15.0,6.2$ $\mathrm{Hz}, 0.64 \mathrm{H}, \mathrm{CH}_{2}$ benz $E 1$ ), 4.37 (dd, $J=15.0,6.2 \mathrm{~Hz}, 0.64 \mathrm{H}, \mathrm{CH}_{2}$ benz $E 1$ ), 4.07 (d, $J=13.8 \mathrm{~Hz}, 0.64 \mathrm{H}, \mathrm{CH}_{2}$ benz $E 1$ ), 4.04 (dd, $J=14.0,6.0 \mathrm{~Hz}, 0.36 \mathrm{H}, \mathrm{CH}_{2}$ benz E2), $3.76(\mathrm{~d}, J=13.8 \mathrm{~Hz}$, $0.64 \mathrm{H}, \mathrm{CH}_{2}$ benz E1), 3.61 (dd, $J=14.0,6.0 \mathrm{~Hz}, 0.36 \mathrm{H}, \mathrm{CH}_{2}$ 
benz $E 2$ ), 3.60 (d, $J=13.5 \mathrm{~Hz}, 0.36 \mathrm{H}, \mathrm{CH}_{2}$ benz $\left.E 2\right), 2.30$ (s, $\left.1.08 \mathrm{H}, \mathrm{CH}_{3} E 2\right), 2.28$ (s, $\left.1.92 \mathrm{H}, \mathrm{CH}_{3} E 1\right) .{ }^{13} \mathrm{C} \mathrm{NMR}(75 \mathrm{MHz}$, $\left.\mathrm{CDCl}_{3}\right) \delta: 171.5,170.0,169.9,168.5,145.5,138.4,138.4,137.9$, 137.2 (Cq E1/E2), $135.1\left(\mathrm{CH}_{\mathrm{Ar}}\right), 134.8,133.6,133.4,131.1(\mathrm{Cq}$ $E 1 / E 2), 131.7,130.7,130.5\left(\mathrm{CH}_{\mathrm{Ar}} E 1 / E 2\right), 130.4(\mathrm{Cq}), 130.2$, $130.0\left(\mathrm{CH}_{\mathrm{Ar}} E 1 / E 2\right), 129.8,129.8$ (Cq $\left.E 1 / E 2\right), 129.5,129.4$, $128.7,128.7,128.6,128.2$, 128.0, 128.0, 127.6, 127.5, 127.4, 125.6, 125.3 $\left(\mathrm{CH}_{\mathrm{Ar}} E 1 / E 2\right), 107.7,105.0$ (Cq E1/E2), 55.8, 53.4, 43.5, $43.2\left(\mathrm{CH}_{2} E 1 / E 2\right), 21.5,21.4\left(\mathrm{CH}_{3} E 1 / E 2\right) . \mathrm{MS}(\mathrm{EI}) \mathrm{m} / \mathrm{z}$ (relative intensity): $521\left(\mathrm{M}^{+}, 6.4\right), 371$ (14), 269 (10), 150 (73), 105 (100), 91 (26). HRMS (EI): calcd for $\mathrm{C}_{31} \mathrm{H}_{27} \mathrm{~N}_{3} \mathrm{O}_{5}\left[\mathrm{M}^{+}\right]$ 521.1951 found 521.1937.

(E)-N-Benzyl-2-[N-(4-methoxybenzyl)- $N$-(2-nitrobenzoyl) amino]3-hydroxy-3-phenylacrylamide 5i. White solid, m.p. 142-143 ${ }^{\circ} \mathrm{C}$ (conformational isomers E1/E2: 57/43). IR ( $\mathrm{KBr}$, $\left.\mathrm{cm}^{-1}\right)$ : $3440(\mathrm{OH}), 1658(\mathrm{C}=\mathrm{O}), 1526,1398,1348 .{ }^{1} \mathrm{H}$ NMR $\left(400 \mathrm{MHz}_{\mathrm{CDCl}}\right) \delta: 15.71(\mathrm{~s}, 0.43 \mathrm{H}, \mathrm{OH} E 2), 15.09(\mathrm{~s}, 0.57 \mathrm{H}$, $\mathrm{OH} E 1), 8.29-6.52\left(\mathrm{~m}, 18 \mathrm{H}, \mathrm{H}_{\mathrm{Ar}} E 1 / E 2\right), 7.07-6.94(\mathrm{~m}, 0.57 \mathrm{H}$, NH E1), 6.51-6.43 (m, 0.43H, NH E2), 5.72 (d, $J=13.6 \mathrm{~Hz}$, $0.43 \mathrm{H}, \mathrm{CH}_{2}$ benz E2), 4.50 (dd, $J=14.9,6.3 \mathrm{~Hz}, 0.57 \mathrm{H}, \mathrm{CH}_{2}$ benz E1), 4.39 (dd, $J=14.9,6.3 \mathrm{~Hz}, 0.57 \mathrm{H}, \mathrm{CH}_{2}$ benz $\left.E 1\right), 4.06$ (dd, $J=14.2,6.0 \mathrm{~Hz}, 0.43 \mathrm{H}, \mathrm{CH}_{2}$ benz $\left.E 2\right), 4.04$ (d, $J=13.9 \mathrm{~Hz}$, $0.57 \mathrm{H}, \mathrm{CH}_{2}$ benz $\left.E 1\right), 3.76$ (d, $J=13.9 \mathrm{~Hz}, 0.57 \mathrm{H}, \mathrm{CH}_{2}$ benz $\left.E 1\right)$, $3.75\left(\mathrm{~s}, 1.32 \mathrm{H}, \mathrm{CH}_{3} E 2\right), 3.72\left(\mathrm{dd}, J=14.2,6.0 \mathrm{~Hz}, 0.43 \mathrm{H}, \mathrm{CH}_{2}\right.$ benz $E 2$ ), $3.72\left(\mathrm{~s}, 1.68 \mathrm{H}, \mathrm{CH}_{3} E 1\right), 3.67$ (dd, $J=14.2,6.0 \mathrm{~Hz}$, $0.43 \mathrm{H}, \mathrm{CH}_{2}$ benz $E 2$ ), 3.60 (d, $J=13.6 \mathrm{~Hz}, 0.43 \mathrm{H}, \mathrm{CH}_{2}$ benz $E 2$ ). ${ }^{13} \mathrm{C}$ NMR $\left(100 \mathrm{MHz} \mathrm{CDCl}_{3}\right) \delta: 171.5,170.3,170.0,168.5,168.5$, $167.8,159.8,159.7,146.8,145.5,137.9,137.1,135.2,134.9(\mathrm{Cq}$ $E 1 / E 2), 133.6\left(\mathrm{CH}_{\mathrm{Ar}}\right), 133.5,133.2(\mathrm{Cq}) 131.7,131.4,131.1$, $130.6,130.2$, 129.4, 128.8, 128.7, 128.7, 128.6, 128.1, 128.0, $127.9,127.6,127.6,127.5,127.4,125.6,125.5$, 125.3, 114.3, $114.0\left(\mathrm{CH}_{\mathrm{Ar}} E 1 / E 2\right), 107.7,104.9$ (Cq E1/E2), $55.5\left(\mathrm{CH}_{3}\right), 55.4$ $\left(\mathrm{CH}_{2}\right), 55.3\left(\mathrm{CH}_{3}\right), 53.1,44.2,43.5,43.3\left(\mathrm{CH}_{2} \mathrm{E1} / \mathrm{E2}\right) . \mathrm{MS}(\mathrm{EI})$ $\mathrm{m} / z$ (relative intensity): $537\left(\mathbf{M}^{+}, 0.6\right), 121$ (32), 105 (100), 91 (48).

(E)- $N$-Benzyl-2-[ $N$-(4-chlorobenzyl)- $N$-(2-nitrobenzoyl)amino]3-hydroxy-3-phenylacrylamide 5j. White solid, m.p. 152-153 ${ }^{\circ} \mathrm{C}$ (conformational isomers E1/E2: 58/42). IR ( $\mathrm{KBr}$, $\left.\mathrm{cm}^{-1}\right): 3427(\mathrm{OH}), 1651(\mathrm{C}=\mathrm{O}), 1538,1393,1353 .{ }^{1} \mathrm{H}$ NMR $\left(300 \mathrm{MHz}, \mathrm{CDCl}_{3}\right) \delta: 15.76(\mathrm{~s}, 0.42 \mathrm{H}, \mathrm{OH} E 2), 15.13(\mathrm{~s}, 0.58 \mathrm{H}$, $\mathrm{OH} E 1), 8.31-6.60\left(\mathrm{~m}, 18 \mathrm{H}, \mathrm{H}_{\mathrm{Ar}}, E 1 / E 2\right), 7.01(\mathrm{t}, J=5.9 \mathrm{~Hz}$, $0.58 \mathrm{H}, \mathrm{NH} E 1), 6.45(\mathrm{t}, J=5.9 \mathrm{~Hz}, 0.42 \mathrm{H}, \mathrm{NH} E 2), 5.72(\mathrm{~d}, J=$ $13.6 \mathrm{~Hz}, 0.42 \mathrm{H}, \mathrm{CH}_{2}$ benz $E 2$ ), 4.56 (dd, $J=14.8,6.5 \mathrm{~Hz}, 0.58 \mathrm{H}$, $\mathrm{CH}_{2}$ benz $E 1$ ), 4.37 (dd, $J=14.8,6.5 \mathrm{~Hz}, 0.58 \mathrm{H}, \mathrm{CH}_{2}$ benz $E 1$ ), 4.07 (d, $J=13.8 \mathrm{~Hz}, 0.58 \mathrm{H}, \mathrm{CH}_{2}$ benz $E 1$ ), 4.04 (dd, $J=14.3,6.5$ $\mathrm{Hz}, 0.42 \mathrm{H}, \mathrm{CH}_{2}$ benz E2), 3.79 (d, $J=13.8 \mathrm{~Hz}, 0.58 \mathrm{H}, \mathrm{CH}_{2}$ benz $E 1), 3.72\left(\mathrm{dd}, J=14.3,6.5 \mathrm{~Hz}, 0.42 \mathrm{H}, \mathrm{CH}_{2}\right.$ benz E2) $3.60(\mathrm{~d}, J=$ $13.6 \mathrm{~Hz}, 0.42 \mathrm{H}, \mathrm{CH}_{2}$ benz E2). ${ }^{13} \mathrm{C} \mathrm{NMR}\left(75 \mathrm{MHz}, \mathrm{CDCl}_{3}\right) \delta$ : $171.8,170.1,169.9,168.7,168.6,167.9,145.5,137.8,137.0(\mathrm{Cq}$ $E 1 / E 2), 135.2\left(\mathrm{CH}_{\mathrm{Ar}}\right), 134.7(\mathrm{Cq}), 133.4\left(\mathrm{CH}_{\mathrm{Ar}}\right), 133.2(\mathrm{Cq}), 131.9$ $\left(\mathrm{CH}_{\mathrm{Ar}}\right), 131.8(\mathrm{Cq}), 131.5,131.2,130.8,130.7,130.4,129.5$, 129.3 , 128.9, 128.7, 128.2, 128.1, 127.8, 127.6, 127.6, 125.7, $125.4\left(\mathrm{CH}_{\mathrm{Ar}} E 1 / E 2\right), 107.7,104.6$ (Cq $\left.E 1 / E 2\right), 55.2,53.2,43.5$, $43.4\left(\mathrm{CH}_{2} E 1 / E 2\right)$. MS (EI) $m / z$ (relative intensity): $541\left(\mathrm{M}^{+}, 24\right)$, $543\left(\mathrm{M}^{+}+2,10\right), 391$ (65), 393 (23), 253 (26), 150 (100), 125(98), 105 (63), 91 (57), 77 (30). HRMS (EI): calcd for $\mathrm{C}_{30} \mathrm{H}_{24} \mathrm{ClN}_{3} \mathrm{O}_{5}$ $\left[\mathrm{M}^{+}\right] 541.1404$ found 541.1412 .
General procedure for the synthesis of Ugi adducts 9a-c

1

The $o$-nitrobenzylamine hydrochloride $7(0.207 \mathrm{~g}, 1.1 \mathrm{mmol})$ was treated with a solution of $\mathrm{KOH}(1.0 \mathrm{mmol})$ in ethanol for $10 \mathrm{~min}$, after which the phenylglyoxal hydrate 1a $(0.152 \mathrm{~g}$, $1 \mathrm{mmol}$ ) was added. The mixture was stirred for $15 \mathrm{~min}$ at room temperature. Then, the corresponding carboxylic acid $\mathbf{8 a}-\mathbf{b}(1 \mathrm{mmol})$ and isocyanide $\mathbf{4 a}-\mathbf{b}(1 \mathrm{mmol})$ were added and the mixture was stirred for 2 days until a solid precipitated. The solid was filtered and recrystallized from i-PrOH-i- $\mathrm{Pr}_{2} \mathrm{O}$.

(E)-N-Benzyl-2-[ $N$-(2-nitrobenzyl)- $N$-benzoylamino]-3-hydroxy3-phenylacrylamide 9a. White solid, m.p. 177-178 ${ }^{\circ} \mathrm{C}$. IR $\left(\mathrm{KBr}, \mathrm{cm}^{-1}\right): 3483(\mathrm{OH}), 1670(\mathrm{C}=\mathrm{O}), 1543,1393 .{ }^{1} \mathrm{H} \mathrm{NMR}$ (300 MHz, DMSO- $d_{6}$ ) (as a mixture of tautomers and conformers) $\delta: 15.38(\mathrm{~s}, 0.50 \mathrm{H}, \mathrm{OH}$ enol $E 1), 15.34(\mathrm{~s}, 0.13 \mathrm{H}, \mathrm{OH}$ enol $E 2), 9.46$ (t, $J=5.3 \mathrm{~Hz}, 0.50 \mathrm{H}, \mathrm{NH} E 1), 9.24(\mathrm{t}, J=5.0 \mathrm{~Hz}, 0.37 \mathrm{H}$, $\mathrm{NH}$ keto), 9.06 (t, $J=5.1 \mathrm{~Hz}, 0.13 \mathrm{H}$, NH enol $E 2), 8.00-6.63(\mathrm{~m}$, $\left.19 \mathrm{H}, \mathrm{H}_{\mathrm{Ar}}\right), 6.08(\mathrm{~s}, 0.37 \mathrm{H}, \mathrm{CH}$ keto), 5.39-4.78 (m, 2H), 4.58-3.65 (m, 2H). ${ }^{13} \mathrm{C}$ NMR (75 MHz, DMSO- $\left.d_{6}\right) \delta:$ 194.7, $193.2,173.1,172.9,171.6,170.6,165.4,148.5,147.9,138.6$, $138.4,135.8,135.5,135.1,134.5,134.3,134.0,133.9,133.7$, $130.7,129.6,129.4,129.3,129.1,129.0,128.9,128.6,128.5$, $128.4,128.1,128.0,127.7,127.1,126.6,125.5,125.0,109.2$, 68.0, 64.8, 49.6, 46.0, 43.1. MS (EI) $\mathrm{m} / \mathrm{z}$ (relative intensity): 400 (18), 104 (100), 90 (36).

$(E)-N$-Cyclohexyl-2-[ $N$-(2-nitrobenzyl)- $N$-(2-bromobenzoyl)amino]-3-hydroxy-3-phenylacrylamide 9b. White solid. M.p. dec. $\left(>180{ }^{\circ} \mathrm{C}\right) \cdot(E 1 / E 2: 61 / 39)$. IR (KBr, cm $\left.{ }^{-1}\right)$ : $3393(\mathrm{OH}), 1651$ (CO), 1632 (CO), 1537, 1524, 1381, 1344. ${ }^{1} \mathrm{H}$ NMR $(300 \mathrm{MHz}$, $\left.\mathrm{CDCl}_{3}\right) \delta: 15.68(\mathrm{~s}, 0.39 \mathrm{H}, \mathrm{OH}$ enol $E 2), 15.13(\mathrm{~s}, 0.61 \mathrm{H}, \mathrm{OH}$ enol E1), 7.91-6.99 (m, 13H, $\left.\mathrm{H}_{\mathrm{Ar}}\right), 6.11(\mathrm{~d}, J=8.1 \mathrm{~Hz}, 0.61 \mathrm{H}$, NH enol E1), 5.91 (d, $J=8.1 \mathrm{~Hz}, 0.39 \mathrm{H}, \mathrm{NH}$ enol E2), 5.85 (d, $J=14.1 \mathrm{~Hz}, 0.61 \mathrm{H}$, enol $E 1), 4.73(\mathrm{~d}, J=14.1 \mathrm{~Hz}, 0.39 \mathrm{H}$, enol $E 2$ ), 4.19 (d, $J=14.1 \mathrm{~Hz}, 0.39 \mathrm{H}$, enol $E 2), 4.05$ (d, $J=14.1 \mathrm{~Hz}$, $0.61 \mathrm{H}$, enol $E 1), 3.71-3.62(\mathrm{~m}, 0.61 \mathrm{H}$, enol $E 1), 3.33-3.22(\mathrm{~m}$, $0.39 \mathrm{H}$, enol E2), 2.01-0.56 (m, 10H). ${ }^{13} \mathrm{C} \mathrm{NMR}$ (75 MHz, $\mathrm{CDCl}_{3}$ ) $\delta: 171.3,170.4,170.0,169.4,168.4,168.9,168.5$ (Cq enol $E 1 /$ E2), 133.6, 133.5, 133.1, 131.0, 130.8, 127.7, 129.6, 129.5, 128.8, 128.6, 128.1, 128.0, 127.8, 127.7, 127.6, 126.8, 125.1, 124.9 $\left(\mathrm{CH}_{\mathrm{Ar}}\right.$ enol E1/E2), $109.9(\mathrm{Cq}), 50.7\left(\mathrm{CH}_{2}\right), 48.9(\mathrm{CH}), 46.9$ $\left(\mathrm{CH}_{2}\right)$, 33.3, 32.7, 32.2, 31.9, 25.6, 25.4, 25.3, 25.2, $24.7\left(\mathrm{CH}_{2}\right.$ enol $E 1 / E 2)$. MS (EI) $m / z$ (relative intensity): $577\left(\mathrm{M}^{+}, 0.07\right), 579$ (M + 2, 0.09), 269 (28), 183 (92), 185 (88), 105 (100), 77 (28). HRMS (EI): calcd for $\mathrm{C}_{29} \mathrm{H}_{28} \mathrm{BrN}_{3} \mathrm{O}_{5} 577.1212$ found 577.1202 .

$(E)-N$-Benzyl-2-[ $N$-(2-nitrobenzyl)- $N$-(2-bromobenzoyl)amino]3-hydroxy-3-phenylacrylamide 9c. White solid, m.p. 157-158 ${ }^{\circ} \mathrm{C}$ (E1/E2: 60/40). IR (KBr, cm $\left.{ }^{-1}\right): 3273(\mathrm{OH}), 1699$ (CO), 1677 (CO), 1449, 1343, 1288, 1258. ${ }^{1} \mathrm{H}$ NMR (300 MHz, $\left.\mathrm{CDCl}_{3}\right) \delta: 15.41(\mathrm{~s}, 0.4 \mathrm{H}, \mathrm{OH}$ enol $E 2), 14.91(\mathrm{~s}, 0.6 \mathrm{H}, \mathrm{OH}$ enol $E 1), 7.94-6.85\left(\mathrm{~m}, 18.4 \mathrm{H}, \mathrm{H}_{\mathrm{Ar}}+N H E 2\right), 6.51(\mathrm{t}, J=5.2 \mathrm{~Hz}$, $0.6 \mathrm{H}, \mathrm{NH} E 1$ ), 5.79 (d, $J=13.9 \mathrm{~Hz}, 0.4 \mathrm{H}$, enol $E 2), 4.66$ (d, $J=$ $14.1 \mathrm{~Hz}, 0.6 \mathrm{H}$, enol E1), 4.45-4.24 (m, 2H), 4.26 (d, $J=14.1 \mathrm{~Hz}$, $0.6 \mathrm{H}$, enol $E 1$ ), 4.08 (d, $J=13.9 \mathrm{~Hz}, 0.4 \mathrm{H}$, enol $E 2) .{ }^{13} \mathrm{C} \mathrm{NMR}$ $\left(75 \mathrm{MHz}, \mathrm{CDCl}_{3}\right) \delta: 171.7,170.7,170.1,170.0,169.4,168.3$, 149.6, 149.4, 137.2, 137.0, 136.5, 134.1 (Cq E1/E2), 133.8, 133.7 $\left(\mathrm{CH}_{\mathrm{Ar}} E 1 / E 2\right), 133.5$ (Cq) 133.4, 133.3, 133.1, 132.9, 131.7, 
131.3, 131.0, $130.9\left(\mathrm{CH}_{\mathrm{Ar}} E 1 / E 2\right), 130.0$ (Cq), 129.7, 129.6, 129.5, 129.0, 128.9, 128.8, $128.6\left(\mathrm{CH}_{\mathrm{Ar}} E 1 / E 2\right), 128.5(\mathrm{Cq})$, $128.4,128.2$, 128.1, 128.0, 127.9, 127.7, 127.6, 126.9, 125.1, $125.0\left(\mathrm{CH}_{\mathrm{Ar}} E 1 / E 2\right), 120.5,120.0,106.9,104.0$ (Cq E1/E2), 50.6, 46.6, 44.1, $43.0\left(\mathrm{CH}_{2} E 1 / E 2\right)$. MS (EI) $\mathrm{m} / z$ (relative intensity): 585 ( $\left.\mathrm{M}^{+}, 0.3\right), 587$ (M + 2, 0.28), 185 (100), 105 (86), 91 (53), 77 (29). HRMS (EI): calcd for $\mathrm{C}_{30} \mathrm{H}_{24} \mathrm{BrN}_{3} \mathrm{O}_{5} 585.0899$ found 585.0903 .

\section{Procedure for the synthesis of Ugi adduct 9d}

The o-nitrobenzylamine hydrochloride $7(0.207 \mathrm{~g}, 1.1 \mathrm{mmol})$ was treated with a solution of $\mathrm{KOH}(1.0 \mathrm{mmol})$ in ethanol for $10 \mathrm{~min}$, after which the phenylglyoxal hydrate 1a $(0.152 \mathrm{~g}$, $1 \mathrm{mmol}$ ) was added. The mixture was stirred for $15 \mathrm{~min}$ at room temperature. Then, the terephthalic acid 8c $(0.083 \mathrm{~g}$, $0.5 \mathrm{mmol})$ and the cyclohexylisocyanide $4 \mathrm{a}(0.109 \mathrm{~g}, 1 \mathrm{mmol})$ were added and the mixture was stirred for 2 days until a solid precipitated. The solid was filtered and recrystallized from $\mathrm{MeOH}-\mathrm{DMF}$.

$N^{1}, N^{4}$-Bis $((E)$-1-cyclohexylaminocarbonyl-2-hydroxy-2-phenylethenyl)- $N^{1}, N^{4}$-bis(2-nitrobenzyl)terephthalamide 9d. White solid, m.p. $214-216^{\circ} \mathrm{C}$. IR ( $\left.\mathrm{KBr}, \mathrm{cm}^{-1}\right)$ : 3333 (OH), 1650 (CO), 1609, 1377, 1530, 1314. ${ }^{1} \mathrm{H}$ NMR (400 MHz, $\left.\mathrm{CDCl}_{3}\right) \delta$ : (principal conformer) 15.32 (s, 2H, OH enol), 8.42-6.70 (m, $22 \mathrm{H}$, $\left.\mathrm{H}_{\mathrm{Ar}}\right), 5.88-5.78(\mathrm{~m}, 3 \mathrm{H}), 4.16(\mathrm{~d}, J=15 \mathrm{~Hz}, 2 \mathrm{H}), 3.62-3.40(\mathrm{~m}$, $2 \mathrm{H}), 1.62-0.72(\mathrm{~m}, 20 \mathrm{H}) .{ }^{13} \mathrm{C}$ NMR $\left(100 \mathrm{MHz}, \mathrm{CDCl}_{3}\right) \delta$ : (principal conformer) $171.2(\mathrm{Cq}), 169.7(\mathrm{Cq}), 169.5(\mathrm{Cq}), 137.3(\mathrm{Cq})$, $133.8\left(\mathrm{CH}_{\mathrm{Ar}}\right), 132.2\left(\mathrm{CH}_{\mathrm{Ar}}\right), 131.2\left(\mathrm{CH}_{\mathrm{Ar}}\right), 131.0\left(\mathrm{CH}_{\mathrm{Ar}}\right), 129.5$ $\left(\mathrm{CH}_{\mathrm{Ar}}\right), 129.1\left(\mathrm{CH}_{\mathrm{Ar}}\right), 129.0\left(\mathrm{CH}_{\mathrm{Ar}}\right), 127.7\left(\mathrm{CH}_{\mathrm{Ar}}\right), 127.7\left(\mathrm{CH}_{\mathrm{Ar}}\right)$, $126.9\left(\mathrm{CH}_{\mathrm{Ar}}\right), 125.1\left(\mathrm{CH}_{\mathrm{Ar}}\right), 108.5(\mathrm{Cq}), 49.0\left(\mathrm{CH}_{2}\right), 48.4\left(\mathrm{CH}_{2}\right)$, $48.3(\mathrm{CH}), 33.0\left(\mathrm{CH}_{2}\right), 32.5\left(\mathrm{CH}_{2}\right), 32.3\left(\mathrm{CH}_{2}\right), 25.3\left(\mathrm{CH}_{2}\right), 25.0$ $\left(\mathrm{CH}_{2}\right), 24.8\left(\mathrm{CH}_{2}\right) \cdot \mathrm{MS}\left(\mathrm{FAB}^{+}\right) \mathrm{m} / z$ (relative intensity): $921\left(\mathrm{M}^{+}+\right.$ 1, 32), $922\left(\mathrm{M}^{+}+2,23\right), 822$ (100), 823 (49), 526 (54).

\section{General procedure for the synthesis of benzodiazepines $6 a-j$}

To a suspension of enol $\mathbf{5 a - j}(0.5 \mathrm{mmol})$ in ethanol $(10 \mathrm{~mL})$ and hydrochloric acid solution $0.6 \mathrm{M}(1.5 \mathrm{mmol})$ was added stannous chloride $(5 \mathrm{mmol})$. The reaction was refluxed for $45 \mathrm{~min}$, cooled and concentrated under reduced pressure. The residue was dissolved in dichloromethane and washed with a diluted $\mathrm{KOH}$ solution and then with water. The organic extract was dried with $\mathrm{Na}_{2} \mathrm{SO}_{4}$ and concentrated. The crude residue was recrystallized from methanol.

Compounds $6 \mathbf{6}-\mathbf{e}$ have been previously described. ${ }^{4}$

$\mathrm{N}$-Cyclohexyl-4-benzyl-5-oxo-2-(4-fluorophenyl)-4,5-dihydro$3 \boldsymbol{H}$-benzo[ $\boldsymbol{e}][\mathbf{1 , 4}]$ diazepino-3-carboxamide (6f). White solid, m.p. $176-177{ }^{\circ} \mathrm{C}$. IR $\left(\mathrm{KBr}, \mathrm{cm}^{-1}\right): 3323(\mathrm{NH}), 3065\left(\mathrm{C}_{\mathrm{Ar}}\right), 2931$, 2855, $1681(\mathrm{C}=\mathrm{O}), 1622(\mathrm{C}=\mathrm{O}), 1515,1454 .{ }^{1} \mathrm{H} \quad \mathrm{NMR}$ $\left(300 \mathrm{MHz} \mathrm{CDCl}_{3}\right) \delta: 8.01-7.04\left(\mathrm{~m}, 13 \mathrm{H}, \mathrm{H}_{\mathrm{Ar}}\right), 5.22(\mathrm{~s}, 1 \mathrm{H}), 5.14$ (d, $J=14.3 \mathrm{~Hz}, 1 \mathrm{H}, \mathrm{CH}_{2}$ benz), 5.11 (d, $J=8.1 \mathrm{~Hz}, 1 \mathrm{H}, \mathrm{NH}$ ), 4.60 (d, $J=14.3 \mathrm{~Hz}, 1 \mathrm{H}, \mathrm{CH}_{2}$ benz), 3.26-3.13 (m, 1H, CH), 1.95-0.95 (m, 8H), 0.61-0.40 (m, 2H). ${ }^{13} \mathrm{C} \mathrm{NMR}(75 \mathrm{MHz}$, $\left.\mathrm{CDCl}_{3}\right) \delta: 167.5(\mathrm{Cq}), 164.6\left(\mathrm{~d},{ }^{1} J=252.5 \mathrm{~Hz}, \mathrm{Cq}\right), 164.4(\mathrm{Cq})$, $163.6(\mathrm{Cq}), 146.1(\mathrm{Cq}), 136.4(\mathrm{Cq}), 132.3\left(\mathrm{CH}_{\mathrm{Ar}}\right), 130.7\left(\mathrm{CH}_{\mathrm{Ar}}\right)$, $129.9\left(\mathrm{CH}_{\mathrm{Ar}}\right), 129.8\left(\mathrm{CH}_{\mathrm{Ar}}\right), 129.4\left(\mathrm{CH}_{\mathrm{Ar}}\right), 129.0\left(\mathrm{CH}_{\mathrm{Ar}}\right), 128.7$ $\left(\mathrm{CH}_{\mathrm{Ar}}\right), 127.2\left(\mathrm{CH}_{\mathrm{Ar}}\right), 126.4\left(\mathrm{CH}_{\mathrm{Ar}}\right), 125.8(\mathrm{Cq}), 115.8\left(\mathrm{~d},{ }^{2} \mathrm{~J}=\right.$ $\left.21.7 \mathrm{~Hz}, \mathrm{CH}_{\mathrm{Ar}}\right), 59.2(\mathrm{CH}), 52.9\left(\mathrm{CH}_{2}\right), 48.1(\mathrm{CH}), 32.3\left(\mathrm{CH}_{2}\right)$, $32.2\left(\mathrm{CH}_{2}\right), 25.2\left(\mathrm{CH}_{2}\right), 24.7\left(\mathrm{CH}_{2}\right), 24.5\left(\mathrm{CH}_{2}\right) . \mathrm{MS}(\mathrm{EI}) \mathrm{m} / \mathrm{z}$ (relative intensity) $469\left(\mathrm{M}^{+}, 6.9\right), 344$ (100), 253 (48), 227 (15), 197 (16), 91 (45). HRMS (EI): calcd for $\mathrm{C}_{29} \mathrm{H}_{28} \mathrm{FN}_{3} \mathrm{O}_{2}\left[\mathrm{M}^{+}\right]$ 469.2166 found 469.2168 .

$N$,4-Dibenzyl-5-oxo-2-phenyl-4,5-dihydro-3H-benzo[ $e][1,4] \mathrm{di}-$ azepino-3-carboxamide (6g). White solid, m.p. $180-181{ }^{\circ} \mathrm{C}$. IR $\left(\mathrm{KBr}, \mathrm{cm}^{-1}\right): 3327(\mathrm{NH}), 3027,1682(\mathrm{C}=\mathrm{O}), 1633 .{ }^{1} \mathrm{H} \mathrm{NMR}$ $\left(300 \mathrm{MHz}, \mathrm{CDCl}_{3}\right) \delta: 8.03-6.67\left(\mathrm{~m}, 19 \mathrm{H}, \mathrm{H}_{\mathrm{Ar}}\right), 5.67-5.48(\mathrm{~m}$, $1 \mathrm{H}, \mathrm{NH}), 5.34(\mathrm{~s}, 1 \mathrm{H}), 5.08$ (d, $\left.J=14.6 \mathrm{~Hz}, 1 \mathrm{H}, \mathrm{CH}_{2} \mathrm{benz}\right), 4.70$ (d, $J=14.6 \mathrm{~Hz}, 1 \mathrm{H}, \mathrm{CH}_{2}$ benz), 3.95-3.79 (m, 2H, $\mathrm{CH}_{2}$ benz). ${ }^{13} \mathrm{C}$ NMR (75 MHz, $\mathrm{CDCl}_{3}$ ) $\delta: 167.5(\mathrm{Cq}), 165.6(\mathrm{Cq}), 164.2(\mathrm{Cq})$, $146.0(\mathrm{Cq}), 137.7(\mathrm{Cq}), 136.7(\mathrm{Cq}), 136.3(\mathrm{Cq}), 132.3\left(\mathrm{CH}_{\mathrm{Ar}}\right)$, $131.2\left(\mathrm{CH}_{\mathrm{Ar}}\right), 130.7\left(\mathrm{CH}_{\mathrm{Ar}}\right), 129.2\left(\mathrm{CH}_{\mathrm{Ar}}\right), 128.9\left(\mathrm{CH}_{\mathrm{Ar}}\right), 128.8$ $\left(\mathrm{CH}_{\mathrm{Ar}}\right), 128.6\left(\mathrm{CH}_{\mathrm{Ar}}\right), 128.5\left(\mathrm{CH}_{\mathrm{Ar}}\right) 127.8\left(\mathrm{CH}_{\mathrm{Ar}}\right), 127.6\left(\mathrm{CH}_{\mathrm{Ar}}\right)$, 127.4 $\left(\mathrm{CH}_{\mathrm{Ar}}\right), 126.6\left(\mathrm{CH}_{\mathrm{Ar}}\right), 125.8(\mathrm{Cq}), 59.1(\mathrm{CH}), 52.9\left(\mathrm{CH}_{2}\right)$, $43.8\left(\mathrm{CH}_{2}\right)$. MS (EI) $\mathrm{m} / z$ (relative intensity) $459\left(\mathrm{M}^{+}, 11\right), 326$ (24), 325 (16), 235 (11), 91 (100). HRMS (EI): calcd for $\mathrm{C}_{30} \mathrm{H}_{25} \mathrm{~N}_{3} \mathrm{O}_{2}\left[\mathrm{M}^{+}\right] 459.1947$ found 459.1943.

$\mathrm{N}$-Benzyl-4-(4-methylbenzyl)-5-oxo-2-phenyl-4,5-dihydro-3Hbenzo $[e][1,4]$ diazepino-3-carboxamide (6h). White solid, m.p. 139-140 ${ }^{\circ} \mathrm{C}$. IR $\left(\mathrm{KBr}, \mathrm{cm}^{-1}\right): 3327(\mathrm{NH}), 3027,1682(\mathrm{C}=\mathrm{O})$, 1633. ${ }^{1} \mathrm{H}$ NMR $\left(300 \mathrm{MHz}, \mathrm{CDCl}_{3}\right) \delta: 8.02-6.65\left(\mathrm{~m}, 18 \mathrm{H}, \mathrm{H}_{\mathrm{Ar}}\right)$, 5.65-5.54 (m, 1H, NH), $5.33(\mathrm{~s}, 1 \mathrm{H}), 5.01(\mathrm{~d}, J=14.6 \mathrm{~Hz}, 1 \mathrm{H}$, $\mathrm{CH}_{2}$ benz), 4.67 (d, $J=14.6 \mathrm{~Hz}, 1 \mathrm{H}, \mathrm{CH}_{2}$ benz), 3.94-3.84 (m, $2 \mathrm{H}, \mathrm{CH}_{2}$ benz), 2.22 (s, 3H). $\left.{ }^{13} \mathrm{C} \mathrm{NMR} \mathrm{(75} \mathrm{MHz} \mathrm{CDCl}_{3}\right) \delta: 167.4$ $(\mathrm{Cq}), 165.7(\mathrm{Cq}), 164.3(\mathrm{Cq}), 146.0(\mathrm{Cq}), 138.3(\mathrm{Cq}), 137.7(\mathrm{Cq})$, $136.7(\mathrm{Cq}), 133.2(\mathrm{Cq}), 132.2\left(\mathrm{CH}_{\mathrm{Ar}}\right), 131.0(\mathrm{Cq}), 130.7\left(\mathrm{CH}_{\mathrm{Ar}}\right)$, $129.9\left(\mathrm{CH}_{\mathrm{Ar}}\right), 128.9\left(\mathrm{CH}_{\mathrm{Ar}}\right), 128.7\left(\mathrm{CH}_{\mathrm{Ar}}\right), 128.6\left(\mathrm{CH}_{\mathrm{Ar}}\right), 128.4$ $\left(\mathrm{CH}_{\mathrm{Ar}}\right), 127.8\left(\mathrm{CH}_{\mathrm{Ar}}\right), 127.6\left(\mathrm{CH}_{\mathrm{Ar}}\right), 127.5\left(\mathrm{CH}_{\mathrm{Ar}}\right), 127.4\left(\mathrm{CH}_{\mathrm{Ar}}\right)$, $126.5(\mathrm{Cq}), 58.9(\mathrm{CH}), 52.5\left(\mathrm{CH}_{2}\right), 43.8\left(\mathrm{CH}_{2}\right), 21.2\left(\mathrm{CH}_{3}\right) . \mathrm{MS}$ (EI) $m / z$ (relative intensity) $473\left(\mathrm{M}^{+}, 27\right), 340$ (33), 235 (31), 105 (100), 91 (36). HRMS (EI): calcd for $\mathrm{C}_{31} \mathrm{H}_{27} \mathrm{~N}_{3} \mathrm{O}_{2}\left[\mathrm{M}^{+}\right] 473.2103$ found 473.2108 .

$N$-Benzyl-4-(4-methoxybenzyl)-5-oxo-2-phenyl-4,5-dihydro$3 H$-benzo $[e][1,4]$ diazepino-3-carboxamide (6i). White solid, m.p. $144-145^{\circ} \mathrm{C}$. IR (KBr, cm $\left.{ }^{-1}\right): 3333(\mathrm{NH}), 3027 ; 1673(\mathrm{C}=\mathrm{O})$, 1514, 1455, 1248. ${ }^{1} \mathrm{H}$ NMR (300 $\left.\mathrm{MHz}, \mathrm{CDCl}_{3}\right) \delta: 8.08-6.48(\mathrm{~m}$, $\left.18 \mathrm{H}, \mathrm{H}_{\mathrm{Ar}}\right), 5.66-5.53(\mathrm{~m}, 1 \mathrm{H}, \mathrm{NH}), 5.35(\mathrm{~s}, 1 \mathrm{H}), 4.94(\mathrm{~d}, J=14.7$ $\mathrm{Hz}, 1 \mathrm{H}, \mathrm{CH}_{2}$ benz), 4.70 (d, $J=14.7 \mathrm{~Hz}, 1 \mathrm{H}, \mathrm{CH}_{2}$ benz), 3.96-3.83 (m, 2H, $\mathrm{CH}_{2}$ benz), 3.72 (s, 3H). ${ }^{13} \mathrm{C}$ NMR (75 MHz, $\left.\mathrm{CDCl}_{3}\right) \delta: 167.6(\mathrm{Cq}), 165.9(\mathrm{Cq}), 164.5(\mathrm{Cq}), 159.8(\mathrm{Cq}), 146.2$ $(\mathrm{Cq}), 138.0(\mathrm{Cq}), 136.9(\mathrm{Cq}), 132.4\left(\mathrm{CH}_{\mathrm{Ar}}\right), 131.2\left(\mathrm{CH}_{\mathrm{Ar}}\right), 130.8$ $\left(\mathrm{CH}_{\mathrm{Ar}}\right), 130.5\left(\mathrm{CH}_{\mathrm{Ar}}\right), 128.9\left(\mathrm{CH}_{\mathrm{Ar}}\right), 128.8\left(\mathrm{CH}_{\mathrm{Ar}}\right), 128.4(\mathrm{Cq})$, $128.2\left(\mathrm{CH}_{\mathrm{Ar}}\right), 127.9\left(\mathrm{CH}_{\mathrm{Ar}}\right), 127.8\left(\mathrm{CH}_{\mathrm{Ar}}\right), 127.5\left(\mathrm{CH}_{\mathrm{Ar}}\right), 126.7$ $\left(\mathrm{CH}_{\mathrm{Ar}}\right), 126.0(\mathrm{Cq}), 114.7\left(\mathrm{CH}_{\mathrm{Ar}}\right), 59.1(\mathrm{CH}), 55.4\left(\mathrm{CH}_{3}\right), 52.3$ $\left(\mathrm{CH}_{2}\right), 44.0\left(\mathrm{CH}_{2}\right) . \mathrm{MS}(\mathrm{EI}) \mathrm{m} / \mathrm{z}$ (relative intensity) $489\left(\mathrm{M}^{+}, 13\right)$, 356 (12), 235 (19), 121 (100), 91 (22). HRMS (EI): calcd for $\mathrm{C}_{31} \mathrm{H}_{27} \mathrm{~N}_{3} \mathrm{O}_{3}\left[\mathrm{M}^{+}\right]$489.2052; found 489.2042.

$\mathrm{N}$-Benzyl-4-(4-chlorobenzyl)-5-oxo-2-phenyl-4,5-dihydro-3Hbenzo $[e][1,4]$ diazepino-3-carboxamide (6j). White solid, m.p. 177-178 ${ }^{\circ} \mathrm{C}$. IR ( $\left.\mathrm{KBr}, \mathrm{cm}^{-1}\right): 3272(\mathrm{NH}), 1682(\mathrm{C}=\mathrm{O}), 1633$, 1538, 1455. ${ }^{1} \mathrm{H}$ NMR $\left(300 \mathrm{MHz}, \mathrm{CDCl}_{3}\right) \delta: 8.14-6.59(\mathrm{~m}, 18 \mathrm{H}$, $\left.\mathrm{H}_{\mathrm{Ar}}\right), 5.78-5.61(\mathrm{~m}, 1 \mathrm{H}, \mathrm{NH}), 5.27(\mathrm{~s}, 1 \mathrm{H}), 5.06(\mathrm{~d}, J=14.5 \mathrm{~Hz}$, $1 \mathrm{H}, \mathrm{CH}_{2}$ benz), 4.65 (d, $J=14.5 \mathrm{~Hz}, 1 \mathrm{H}, \mathrm{CH}_{2}$ benz), 3.99 (dd, $J=14.5,5.6 \mathrm{~Hz}, 1 \mathrm{H}, \mathrm{CH}_{2}$ benz), $3.90(\mathrm{dd}, J=14.5,5.6 \mathrm{~Hz}, 1 \mathrm{H}$, 
$\mathrm{CH}_{2}$ benz). ${ }^{13} \mathrm{C}$ NMR (75 MHz, $\mathrm{CDCl}_{3}$ ) $\delta: 167.7(\mathrm{Cq}), 165.7(\mathrm{Cq})$, 164.3 (Cq), 146.0 (Cq), 137.6 (Cq), 136.9, 134.9, 134.5, 132.5, $131.4,130.9,130.4,129.3,128.9$, 128.9, 128.0, 127.8, 127.7, 127.6, 126.9, 125.9, $59.6(\mathrm{CH}), 52.5\left(\mathrm{CH}_{2}\right), 44.1\left(\mathrm{CH}_{2}\right) . \mathrm{MS}(\mathrm{EI})$ $\mathrm{m} / \mathrm{z}$ (relative intensity): $493\left(\mathrm{M}^{+}, 30\right), 360$ (72), 235 (57), 179 (31), 150 (31), 127 (32), 125 (100), 121(90), 91 (68). HRMS (EI): calcd for $\mathrm{C}_{30} \mathrm{H}_{24} \mathrm{~N}_{3} \mathrm{O}_{2} \mathrm{Cl}\left[\mathrm{M}^{+}\right]$493.1548; found 493.1557.

\section{General procedure for the synthesis of benzodiazepines 10a-c}

To a suspension of enol 9a-c $(0.5 \mathrm{mmol})$ in ethanol $(10 \mathrm{~mL})$ and hydrochloric acid solution $0.6 \mathrm{M}(1.5 \mathrm{mmol})$ was added stannous chloride $(5 \mathrm{mmol})$. The reaction was refluxed for $45 \mathrm{~min}$, cooled and concentrated under reduced pressure. The residue was dissolved in dichloromethane and washed with a diluted $\mathrm{KOH}$ solution and then with water. The organic extract was dried with $\mathrm{Na}_{2} \mathrm{SO}_{4}$ and concentrated. The crude residue was purified by chromatography (hexane-AcOEt).

4-(Benzoyl)- $\mathrm{N}$-benzyl-2-phenyl-4,5-dihydro-1H-benzo[e][1,4]diazepino-3-carboxamide (10a). Yellow oil (enam1/enam2: 69/ 31). IR ( $\left.\mathrm{KBr}, \mathrm{cm}^{-1}\right): 3423(\mathrm{NH}), 3280(\mathrm{NH}), 1653,1628 .{ }^{1} \mathrm{H}$ NMR $\left(300 \mathrm{MHz} \mathrm{CDCl}_{3}\right) \delta: 8.37-8.34\left(\mathrm{~m}, 1 \mathrm{H}, \mathrm{H}_{\mathrm{Ar}}\right), 7.99(\mathrm{~s}, 0.69$ $\left.\mathrm{H}_{\text {enam1 }}\right) 7.86\left(\mathrm{t}, J=5.3 \mathrm{~Hz}, 0.69 \mathrm{H}, \mathrm{NH}_{\text {enam1 }}\right), 7.55-6.77(\mathrm{~m}, 18 \mathrm{H}$, $\mathrm{H}_{\mathrm{Ar}}$ ), $6.00\left(\mathrm{~s}, 0.31 \mathrm{H}_{\mathrm{enam} 2}\right), 5.71\left(\mathrm{~d}, J=14.2 \mathrm{~Hz}, 0.31 \mathrm{H}_{\mathrm{enam} 2}\right)$, $5.62\left(\mathrm{t}, J=5.4 \mathrm{~Hz}, 0.31 \mathrm{H}, \mathrm{NH}_{\mathrm{enam} 2}\right), 4.71(\mathrm{~d}, J=14.6 \mathrm{~Hz}, 0.69$ $\mathrm{H}_{\text {enam1 }}$ ), 4.51-3.96 (m, 3H). ${ }^{13} \mathrm{C}$ NMR (75 MHz, $\left.\mathrm{CDCl}_{3}\right) \delta: 190.6$, $172.9,171.5,169.1,164.2,146.2,145.4,139,138.2,137.7$, 137.1, 136.6, 136.0, 134.2 (Cq), 132.9, 131.3, 130.6, 130.2, $130.1,129.4,129.2,129.1,129.0,128.9,128.8,128.7,128.4$, $128.1,128.0,127.5,127.4,127.3$, 127.1, 127.0, 125.5, 122.8, 122.3, $119.6\left(\mathrm{CH}_{\mathrm{Ar}}\right), 115.3,114.4,85.0(\mathrm{Cq}), 53.6,48.8,43.8$, $43.8\left(\mathrm{CH}_{2}\right)$. MS (EI) $m / z$ (relative intensity): $459\left(\mathbf{M}^{+}, 7\right), 460$ (M + 1, 4), 370 (22), 264 (24), 105 (100), 91 (24), 77 (40). HRMS (EI): calcd for $\mathrm{C}_{30} \mathrm{H}_{25} \mathrm{~N}_{3} \mathrm{O}_{2} 459.1947$, found 459.1943.

$\mathrm{N}$-Benzyl-4-(bromobenzoyl)-2-phenyl-4,5-dihydro-1H-benzo$[e][1,4]$ diazepino-3-carboxamide (10b).. Yellow solid, m.p. 96-97 ${ }^{\circ} \mathrm{C}$ (enam1/enam2: 20/80). IR (KBr, $\left.\mathrm{cm}^{-1}\right): 3404(\mathrm{NH})$, 3198, 1703 (CO), 1677 (CO), 771, 753, $694 \mathrm{~cm}^{-1} \cdot{ }^{1} \mathrm{H}$ NMR (300 $\left.\mathrm{MHz}, \mathrm{CDCl}_{3}\right) \delta: 7.70-6.65\left(\mathrm{~m}, 13.8 \mathrm{H}, \mathrm{H}_{\mathrm{Ar}}+\mathrm{NH}_{\mathrm{enam} 2}\right), 6.23$ (d, $\left.J=7.3 \mathrm{~Hz}, 0.2 \mathrm{H}, \mathrm{NH}_{\text {enam1 } 1}\right), 6.00\left(\mathrm{~s}, 0.8 \mathrm{H}_{\mathrm{enam} 2}\right), 5.88(\mathrm{~s}, 0.2$ $\mathrm{H}_{\text {enam1}}$ ), 5.67 (d, $\left.J=14.0 \mathrm{~Hz}, 0.8 \mathrm{H}_{\mathrm{enam} 2}\right), 4.71$ (d, $J=15.1 \mathrm{~Hz}$, $0.2 \mathrm{H}_{\text {enam1 }}$ ), 4.56 (d, $\left.J=15.1 \mathrm{~Hz}, 0.2 \mathrm{H}_{\text {enam1}}\right), 4.23$ (d, $J=14.0$ $\mathrm{Hz}, 0.8 \mathrm{H}_{\text {enam2}}$ ), 3.67-3.56 (m, $0.2 \mathrm{H}_{\text {enam1 }}$ ), 3.26-3.161 (m, 0.8 $\mathrm{H}_{\text {enam2 }}$ ), 1.93-0.29 (m, 10H). ${ }^{13} \mathrm{C}$ NMR (75 MHz, $\left.\mathrm{CDCl}_{3}\right) \delta$ : $168.8,164.1,140.5,138.8,137.8,137.6,133.5,132.4$, 131.5, $131.0,130.4,130.2,129.9,129.6,129.4,129.1,128.9,128.6$, $128.5,128.4,127.7,127.6,127.3,127.2,122.1,119.9,119.2$, 113.6, 53.8, 53.4, 47.9, 33.0, 32.2, 25.8, 25.5, 25.0, 24.8. MS (EI) $\mathrm{m} / \mathrm{z}$ (relative intensity): $529\left(\mathrm{M}^{+}, 4\right), 531(\mathrm{M}+2,4), 456(5), 458$ (5), 378 (34), 183 (39), 185 (39), 105 (100), 77 (27). HRMS (EI): calcd for $\mathrm{C}_{29} \mathrm{H}_{28} \mathrm{BrN}_{3} \mathrm{O}_{2} 529.1365$, found 529.1362.

4-(Bromobenzoyl)- $\mathrm{N}$-cyclohexyl-2-phenyl-4,5-dihydro- $\mathbf{H}$ benzo $[e][1,4]$ diazepino-3-carboxamide (10c). Yellow solid, $\mathrm{m}$. p. $124-125{ }^{\circ} \mathrm{C}$ (enam1/enam2: 20/80). IR $\left(\mathrm{KBr}, \mathrm{cm}^{-1}\right): 3434$ $(\mathrm{NH}), 3296(\mathrm{NH}), 1650,1644,1633,1606,1591,753,699 .{ }^{1} \mathrm{H}$ NMR $\left(400 \mathrm{MHz}, \mathrm{CDCl}_{3}\right) \delta: 7.60-6.66\left(\mathrm{~m}, 18.8 \mathrm{H}, \mathrm{H}_{\mathrm{Ar}}+\right.$ $\mathrm{NH}_{\text {enam2}}$ ), 6.22 (d, $\left.J=7.3 \mathrm{~Hz}, 0.2 \mathrm{H}, \mathrm{NH}_{\text {enam1 } 1}\right), 6.04$ (s, 0.8
$\mathrm{H}_{\mathrm{enam} 2}$ ), 5.93 (s, 0.2 $\left.\mathrm{H}_{\mathrm{enam} 1}\right), 5.66\left(\mathrm{~d}, J=14.1 \mathrm{~Hz}, 0.8 \mathrm{H}_{\mathrm{enam} 2}\right)$, $4.71\left(\mathrm{~d}, J=15.6 \mathrm{~Hz}, 0.2 \mathrm{H}_{\mathrm{enam} 1}\right), 4.50$ (d, $J=15.6 \mathrm{~Hz}, 0.2$ $\mathrm{H}_{\text {enam1 }}$ ), 4.42-3.86 (m, 2.8H). $\left.{ }^{13} \mathrm{C} \mathrm{NMR} \mathrm{(100} \mathrm{MHz,} \mathrm{CDCl}_{3}\right) \delta$ : $182.8,182.1,169.3,137.8,137.4,132.7,130.7,130.4,129.99$, 129.2, 128.9, 128.6, 128.5, 128.1, 127.5, 127.0, 122.4, 119.8, 119.2, 112.9, 57.0, 53.4, 43.9. MS (EI) $m / z$ (relative intensity): 537 (M+19), 539 (M + 2, 19), 407 (18), 405 (18), 246 (30), 219 (42), 183 (61), 185 (60), 105 (100), 91 (75). HRMS (EI): calcd for $\mathrm{C}_{30} \mathrm{H}_{24} \mathrm{BrN}_{3} \mathrm{O}_{2}$ 537.1052, found 537.1047.

\section{Procedure for the synthesis of benzodiazepine 10d}

To a suspension of enol $9 \mathrm{~d}(0.5 \mathrm{mmol})$ in ethanol $(10 \mathrm{~mL})$ and hydrochloric acid solution $0.6 \mathrm{M}(3.0 \mathrm{mmol})$ was added stannous chloride $(10 \mathrm{mmol})$. The reaction was refluxed for $45 \mathrm{~min}$, cooled and concentrated under reduced pressure. The residue was dissolved in dichloromethane and washed with a diluted $\mathrm{KOH}$ solution and then with water. The organic extract was dried with $\mathrm{Na}_{2} \mathrm{SO}_{4}$ and concentrated. The crude residue was recrystallized from diisopropyl ether.

4,4'-Terephthaloylbis( $\mathrm{N}$-cyclohexyl-2-phenyl-4,5-dihydro- $1 \mathrm{H}$ benzo $[e][1,4]$ diazepine-3-carboxamide) (10d). White solid, m.p. ${ }^{176}-177^{\circ} \mathrm{C}$ (enam1/enam2: 85/15). IR (KBr, $\left.\mathrm{cm}^{-1}\right): 3324$ $(\mathrm{NH}), 1693,1681,1651 .{ }^{1} \mathrm{H}$ NMR $\left(300 \mathrm{MHz}, \mathrm{CDCl}_{3}\right.$ ) (principal conformer) $\delta:$ 8.33-6.89 (m, 23H, HAr + NH), $4.56(\mathrm{~d}, J=14.8$ $\mathrm{Hz}, 2 \mathrm{H}), 4.35$ (d, $J=14.8 \mathrm{~Hz}, 2 \mathrm{H}), 3.71-3.61$ (m, 2H), 1.79-0.85 $(\mathrm{m}, 20 \mathrm{H}) .{ }^{13} \mathrm{C}$ NMR $\left(75 \mathrm{MHz}, \mathrm{CDCl}_{3}\right.$ ) (principal conformer) $\delta$ : $190.2(\mathrm{Cq}), 171.8(\mathrm{Cq}), 136.8(\mathrm{Cq}), 135.9(\mathrm{Cq}), 133.1\left(\mathrm{CH}_{\mathrm{Ar}}\right)$, $129.2\left(\mathrm{CH}_{\mathrm{Ar}}\right), 129.0\left(\mathrm{CH}_{\mathrm{Ar}}\right), 128.5\left(\mathrm{CH}_{\mathrm{Ar}}\right), 127.4\left(\mathrm{CH}_{\mathrm{Ar}}\right), 125.5$ $\left(\mathrm{CH}_{\mathrm{Ar}}\right), 123.3(\mathrm{Cq}), 84.8(\mathrm{Cq}), 48.8(\mathrm{CH}), 32.5\left(\mathrm{CH}_{2}\right), 32.1\left(\mathrm{CH}_{2}\right)$, $25.6\left(\mathrm{CH}_{2}\right), 24.5\left(\mathrm{CH}_{2}\right), 24.4\left(\mathrm{CH}_{2}\right)$. MS (EI) $\mathrm{m} / \mathrm{z}$ (relative intensity): 388 (25), 361 (26), 256 (78), 235 (87), 149 (100), 105 (93).

\section{Computational methods}

The geometries of all species were fully optimized at the B3LYP/6-31G** level. The environmental effects were taken into account by the Polarizable Continuum Mode (PCM) using the integral equation formalism variant (IEFPCM). ${ }^{21}$ The nature of all optimized structures was determined using harmonic frequency analysis as true minima with no imaginary frequencies or transition states with only one imaginary frequency. All transition state structures and reaction paths were further validated by intrinsic reaction coordinate (IRC) calculations in both forward and reverse directions. All reported energy differences correspond to Gibbs' free energies. All calculations were performed using the Gaussian 09 program. ${ }^{18}$

\section{Acknowledgements}

We gratefully acknowledge financial support from Ministerio de Economía y Competitividad, Spain (project CTQ201231611), from Ministerio de Ciencia e Innovación, Spain and Fondo de Desarrollo Regional (project MAT2011-22781), as well as from Junta de Castilla y León, Consejería de Educación y Cultura y Fondo Social Europeo (project ref. BU246A12-1 and BU327A11-2). 
$1 \quad$ Notes and references

1 S. Marcaccini and T. Torroba, Multicomponent Reactions, ed. J. Zhu and H. Bienaymé, Wiley-VCH, 2005, pp. 33-75.

2 (a) J. A. Robinson, Acc. Chem. Res., 2008, 41, 1278;

(b) Y. Che and G. R. Marshall, Expert Opin. Ther. Targets, 2008, 12, 101; (c) K. Suat and S. D. S. Jois, Curr. Pharm. Des. , 2003, 9, 1209.

3 (a) I. Cerminara, L. Chiummiento, M. Funicello, A. Guarnaccio and P. Lupattelli, Pharmaceuticals, 2012, 5, 297; (b) J. Vagner, H. Qu and V. J. Hruby, Curr. Opin. Chem. Biol., 2008, 12, 292.

4 M. Sañudo, M. García-Valverde, S. Marcaccini, J. J. Delgado, J. Rojo and T. Torroba, J. Org. Chem., 2009, 74, 2189.

5 D. P. Leader and J. Milner-White, Motivated Proteins (http://motif.gla.ac.uk/motif/index.html). Code reference: delta antigen (1A92), LDL receptor module 5 (1AJJ), acetylCoA carboxylase (1BDO), and erabutoxin B (3EBX).

6 S. Gunawan, G. S. Nichol, S. Chappeta, J. Dietrich and C. Hulme, Tetrahedron Lett., 2010, 51, 4689.

7 A. V. Budruev, L. N. Karyakina, O. P. Levina and A. V. Oleinik, Russ. J. Coord. Chem., 2005, 31, 181.

8 S. Bräse, C. Gil, K. Knepper and V. Zimmermann, Angew. Chem., Int. Ed., 2005, 44, 5188.

9 S. Eguchi, ARKIVOC, 2005, ii, 98.
10 B. M. Trost, Angew. Chem., Int. Ed. Engl., 1995, 34, 259.

11 S. Marcaccini and T. Torroba, Nat. Protocols, 2007, 2, 632.

12 S. Marcaccini, M. Miliciani and R. Pepino, Tetrahedron Lett., 2005, 46, 711.

13 A. L. Korich and T. S. Hughes, Synlett, 2007, 2602.

14 B. Morgan and O. Lahav, Chemosphere, 2007, 68, 2080.

15 W.-K. Xing and Y. Ogata, J. Org. Chem., 1982, 47, 3577.

16 (a) J. E. Huber, Tetrahedron Lett., 1968, 9, 3271; (b) C. S. Foote, A. A. Dzakpasu and J. W.-P. Lin, Tetrahedron Lett., 1975, 16, 1274; (c) M. García-Valverde, R. Pedrosa and M. Vicente, Synlett, 2002, 2092.

17 (a) K. M. Rahman, C. H. James and D. E. Thurston, Org. Biomol. Chem., 2011, 9, 1632; (b) J. Seifert, S. Pezeshki, A. Kamal and K. Weisz, Org. Biomol. Chem., 2012, 10, 6850.

18 M. J. Frisch, G. W. Trucks et al., GAUSSIAN 09 program package, Gaussian, Inc., Wallingford CT, 2009.

19 (a) A.-P. Fu, H.-L. Li, D.-M. Du and Z.-Y. Zhou, Chem. Phys. Lett., 2003, 382, 332; (b) S. Tolosa, A. Hidalgo and J. A. Sansón, J. Phys. Chem. B., 2012, 116, 13033.

20 The WHO stability guideline, Stability testing of active pharmaceutical ingredients and finished pharmaceutical products, WHO Technical Report Series, No. 953, Annex 2, 2009.

21 J. Tomasi, B. Mennucci and R. Cammi, Chem. Rev., 2005, 25 105, 2999. 